\title{
ARTE CASTREXA: ESCULTURA E DECORACIÓN ARQUITECTÓNICA
}

\author{
por \\ FRANCISCO CÁLO LOURIDO
}

\begin{abstract}
Ó tema que nos ocupa teño adicado o milleiro de páxinas da miña tese de doutoramento, polo que me vexo obrigado a facer un esforzo sintetizador, remitindo a ela (Calo, 1994) para un estudio máis pormenorizado'. Fago alusión a esto porque a clave para a interpretación da escultura e decoración arquitectónica castrexa, que pasa lóxicamente pola ubicación cronolóxica das máis de 600 pezas que conforman o corpus plástico, foi tratada en profundidade no devandito traballo académico. Aquí e agora teño que converti-las conclusións demostradas ás que cheguei en premisas, en punto de partida para todo o que segue. Se non se aceptan as ditas premisas, pódese cuestionar e tildar de elucubracións tódolos meus argumentos sobre o material escultórico.

Expliquemos, pois, brevemente o método de traballo que seguín no meu estudio.

A Cultura castrexa foi tradicionalmente interpretada como un todo máis ou menos homoxéneo que xurde no Noroeste na primeira metade do I milenio a.C. e que remata xa na nosa Era conforme a romanización a foi eliminando ou desprazando. Datas recurrentes teñen sido ata hai ben pouco
\end{abstract}

\footnotetext{
${ }^{1}$ Este artigo foi exposto como relatorio no marco dun curso de verán da Universidade de Vigo, Campus de Ourense, e entregado para a súa publicación, que non apareceu. Malia o moito tempo transcurrido desde aquela, coido que o interese segue a se-lo mesmo, polo que decidín dalo a coñecer agora na revista do I.E.G.P.S.
}

"CUADERNOS DE ESTUdiOS GALLEGOS", Tomo XLI, Fascículo 106, Santiago 1993-94. 
a do s. VI a.C. para escomenzar e a do s. IV d.C. para rematar. Hoxe é difícil atopar un arqueólogo documentado que ouse trae-lo remate máis acá do s. I d.C., mentras que para os inicios, se ben a tendencia é a leva-los ó s. V a.C., hai investigadores que os retrasan considerablemente. Desde Maluquer (1975) a Almeida (1983) ou Fariña et alii (1983) téñense elaborado varias periodizacións, mellor ou peor demostradas, pero cun punto en común: a oscuridade dos séculos III-II a.C., o que motivou unha tendencia xeral a enchelos cunha serie de pezas claves (fíbulas, xoias...) que realmente aparecen en niveis estratigráficos ou contextos arqueolóxicos moito máis serodios.

Non podemos esquecer que a gran teorización e síntese de López Cuevillas (1953) sobre a Cultura Castrexa se baseou en moi poucos xacementos e hoxe comprobouse que case todos pertencen ó que sería o intre final do Castrexo, que coincide curiosamente co seu período álxido. O que ata agora foi considerado castrexo clásico non é máis que o castrexo dos grandes castros nados baixo Roma ou co seu "floruit" nesa etapa que vai do s. I a.C. ó s. I d.C. Certamente nesto, como en tantas outras manifestacións, tampouco nos diferenciamos do resto da Europa occidental, onde pezas importantes, consideradas tradicionalmente como antigas e célticas, hoxe demostrouse que son recentes; citemos tan só o tan coñecido e citado caldeiro de Gundestrup que resultou ser do s. I a.C. (Cfr. Duval, 1957), ou o Xano de Holzgerlingen, que de ser considerado do VI a.C. pasou a ocupa-lo seu lugar no s. I d.C. (Cfr. Deyts, 1966: 200-202).

$\mathrm{O}$ número de pezas escultóricas castrexas é abundantísimo, pero certamente está inflado por demais. Foi práctica habitual que toda canta peza aparecía - con independencia do lugar - se non encaixaba en ningún estilo pasaba a engrosa-la nómina da plástica castrexa. Esta cultura convirtiuse, xa que logo, nunha especie de caixón de xastre onde todo tiña acollida, elevando a tosquedade e a falta de técnica e oficio do artífice á categoría de estilo.

Sería prolixo en exceso enumera-la cantidade de pezas atopadas nos lugares máis dispares (muros de fincas, paredes de cortes, pinches de casas ou plementería de arcos de igrexas) que pasaron a ser castrexas porque foron atopadas non lonxe dun castro. ¿Que pode haber en Galicia "lonxe" dun castro?. Seguindo este criterio, tan común, a propia catedral de Santiago sería castrexa. O outro parámetro foi, e segue a ser, o da tosquedade. Que nun monte aparece unha gran figura informe..., pois chamámolle "Coloso de Pedralva", convertímolo nunha imaxe fálica e xa temos outra peza para a colección. É obvio que con estes criterios tan pouco científicos 
podemos infla-lo corpus ata onde queiramos (Cfr. Calo, 1976).

A Cultura Castrexa era sen discusión a gran cultura céltica peninsular, logo chegarán os romanos e farán muda-la situación incluída a plástica. Por conseguinte toda a nosa estatuaria tiña que ser prerromana e emparentada, sen pasos intermedios, coas pezas "célticas" francesas, alemanas..., pezas ás que hoxe se lles nega ou cuestiona esa filiación. E, aceptado esto, o paso seguinte, é lóxico, era falar de prerromanismo, indixenismo e rasgos de celtismo ó referirse á plástica provincial romana do Noroeste, caso das estelas ás que moi acertadamente definiu Balil (1978) como obras feitas para "gentes e incolae".

Así estaba a situación cando eu encetei o traballo sobre o tema que nos ocupa, polo que o primeiro paso obrigado foi elaborar un corpus con vocación de totalidade, pero non descontextualizado, xa que eso a nada me levaría, senón rastreando todo tipo de documentación que me permitira adscribi-las pezas a un xacemento concreto. Simultáneamente recopilei e estudiei tódalas referencias bibliográficas de cada un deles e cheguei á conclusión de que tódolos castros documentados naceron ou floreceron a cabalo do cambio de Era ou no s. I d.C. e todo o material plástico susceptible de ser adscrito a un nivel arqueolóxico indefectiblemente había que datalo na época Xulio-Claudia; as pezas atopadas na etapa Flavia apareceron como material reempregado nas novas construccións.

Eis a relación alfabetizada e numerada (para facilita-la ubicación das pezas que citarei) de xacementos que figuran no mapa 1.: 1 Airó, 2 Amorín, 3 Âncora, 4 Anllo, 5 Armea, 6 Assunção, 7 Bagunte, 8 Baltar, 9 Barán, 10 Barbantes, 11 Beiro, 12 Bergazo, 13 Briteiros, 14 Britelo, 15 Cabanca, 16 Capeludos, 17 Carabeles, 18 Castillós, 19 Castromao, 20 Cendufe, 21 Cerdeira, 22 Cividade, 23 Cividáns, 24 Cortes, 25 Cortinhas, 26 Chaves, 27 Eirexario, 28 Elviña, 29 Florderrei Vello, 30 Fontalva, 31 Forca, 32 Francos, 33 Freixo, 34 Galegos, 35 Gaxate, 36 Genço, 37 Grovos, 38 Guarda, 39 Guifões, 40 Lanhoso, 41 Lezenho, 42 Logrosa, 43 Lourizán, 44 Monte Mozinho, 45 Monte Redondo, 46 Montealegre, 47 Moreira Nova, 48 Narla, 49 Nespereira, 50 Ocastro, 51 Óutara, 52 Paço, 53 Paderne, 54 Perozelo, 55 Pontedeume, 56 Remesar, 57 Río, 58 Rioxa, 59 Roriz, 60 Rubiás, 61 Sabanle, 62 Sabroso, 63 Saia, 64 S. Cibrán de Las, 65 S. Jorge de Vizela, 66 S. Julião, 67 S. Marcos, 68 S. Miguel-o-Anjo, 69 S. Miguelo-Anjo, 70 S. Paio de Meixedo, 71 Sanfins, 72 Santa Águeda, 73 Santa Comba, 74 Santa Iria, 75 Santa Luzia, 76 Santa Marinha de Zêzere, 77 Santa Trega, 78 Santo Ovidio de Fafe, 79 Santomé, 80 Sendim, 81 Sete Pías, 82 Terroso, 83 Torres de Oeste, 84 Tortoreos, 85 Três Minas, 86 


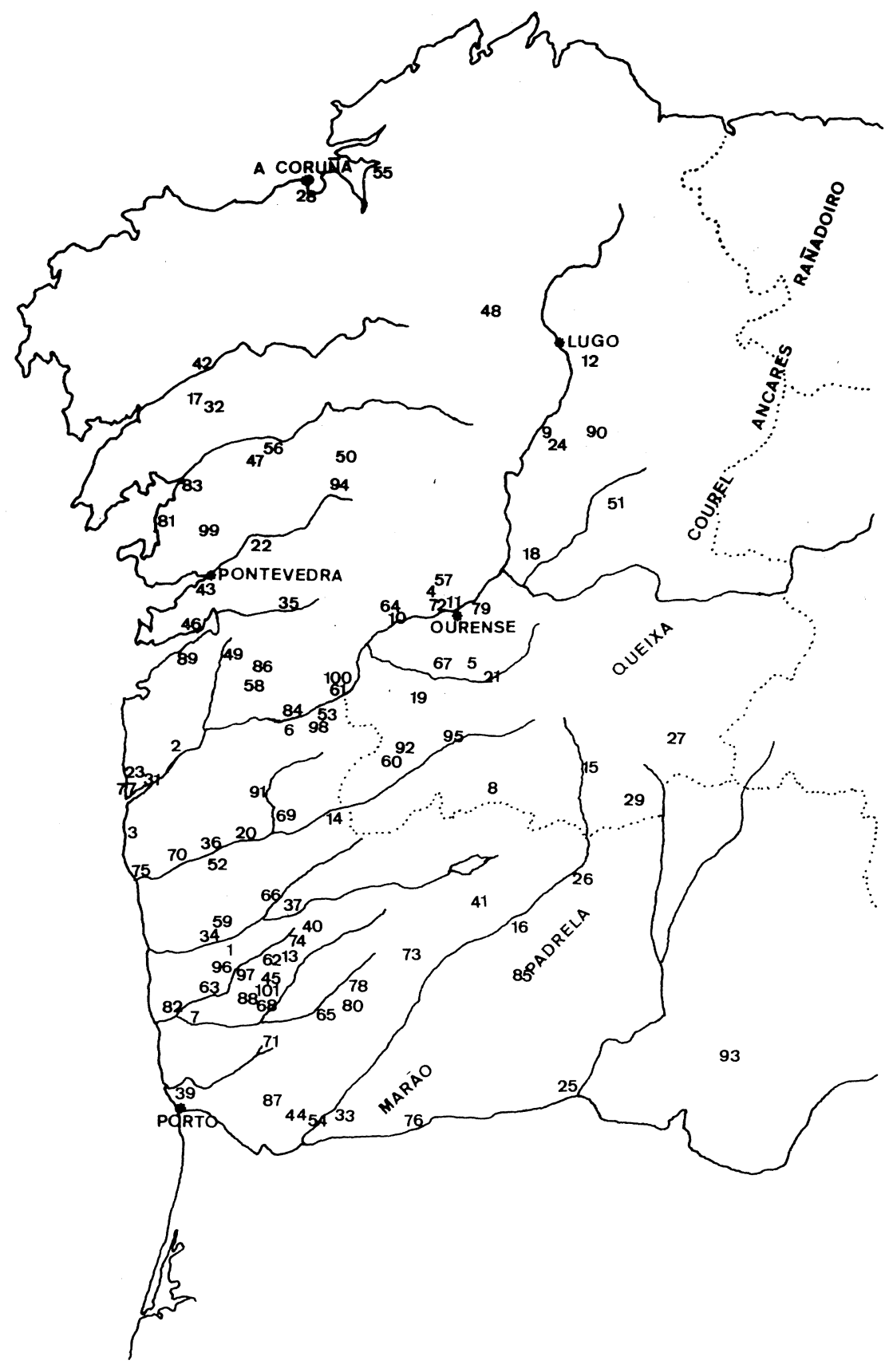

Mapa 1.- Totalidade dos xacementos castrexos con manifestacións plásticas. Os números corresponden á orde alfabética do inventario. 


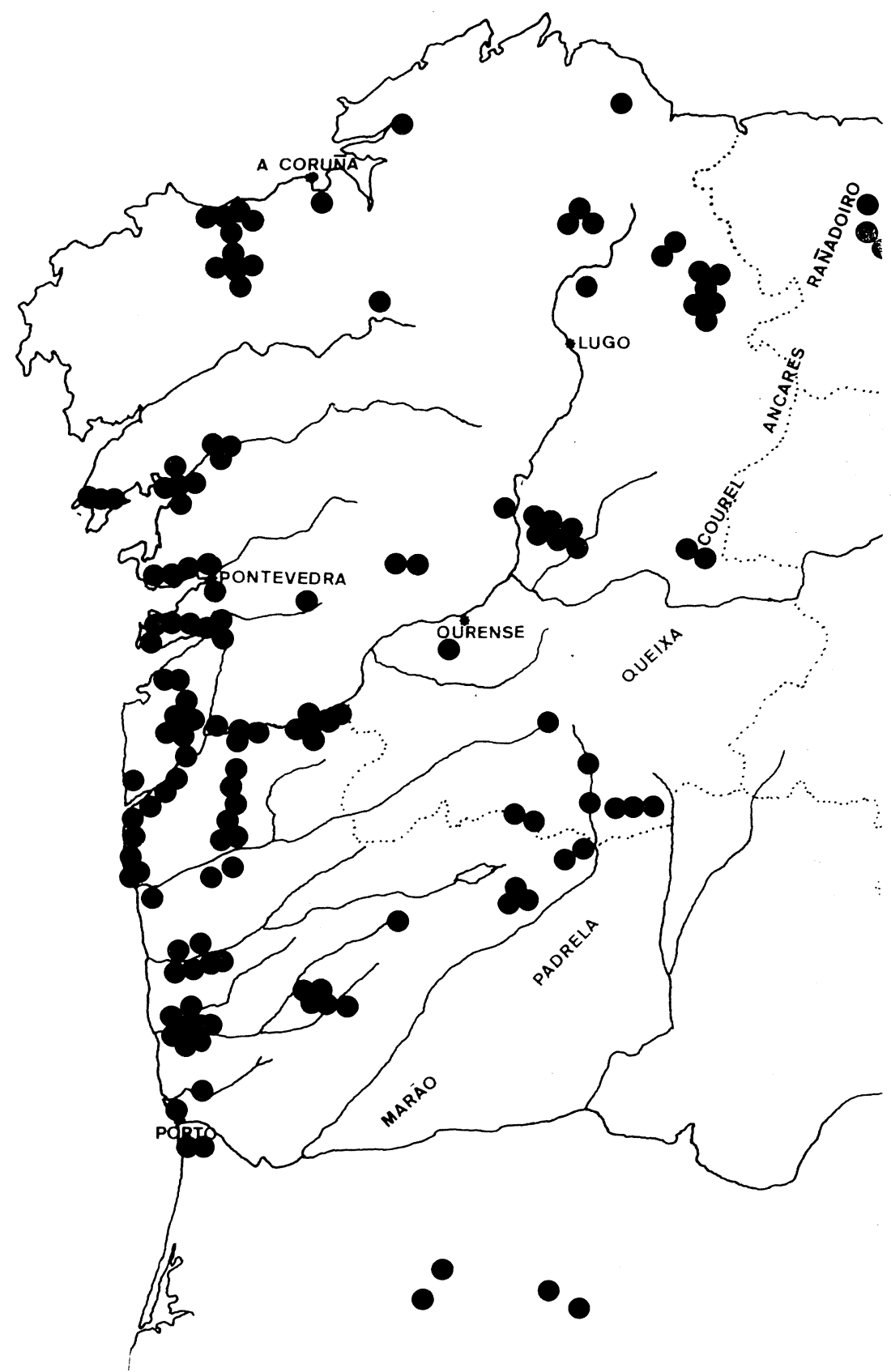

Mapa 2.- Dispersión dos machados da última fase do Bronce Final (Segundo MONTEAGUDO, 1977 e CALO-SIERRA. 1983). 


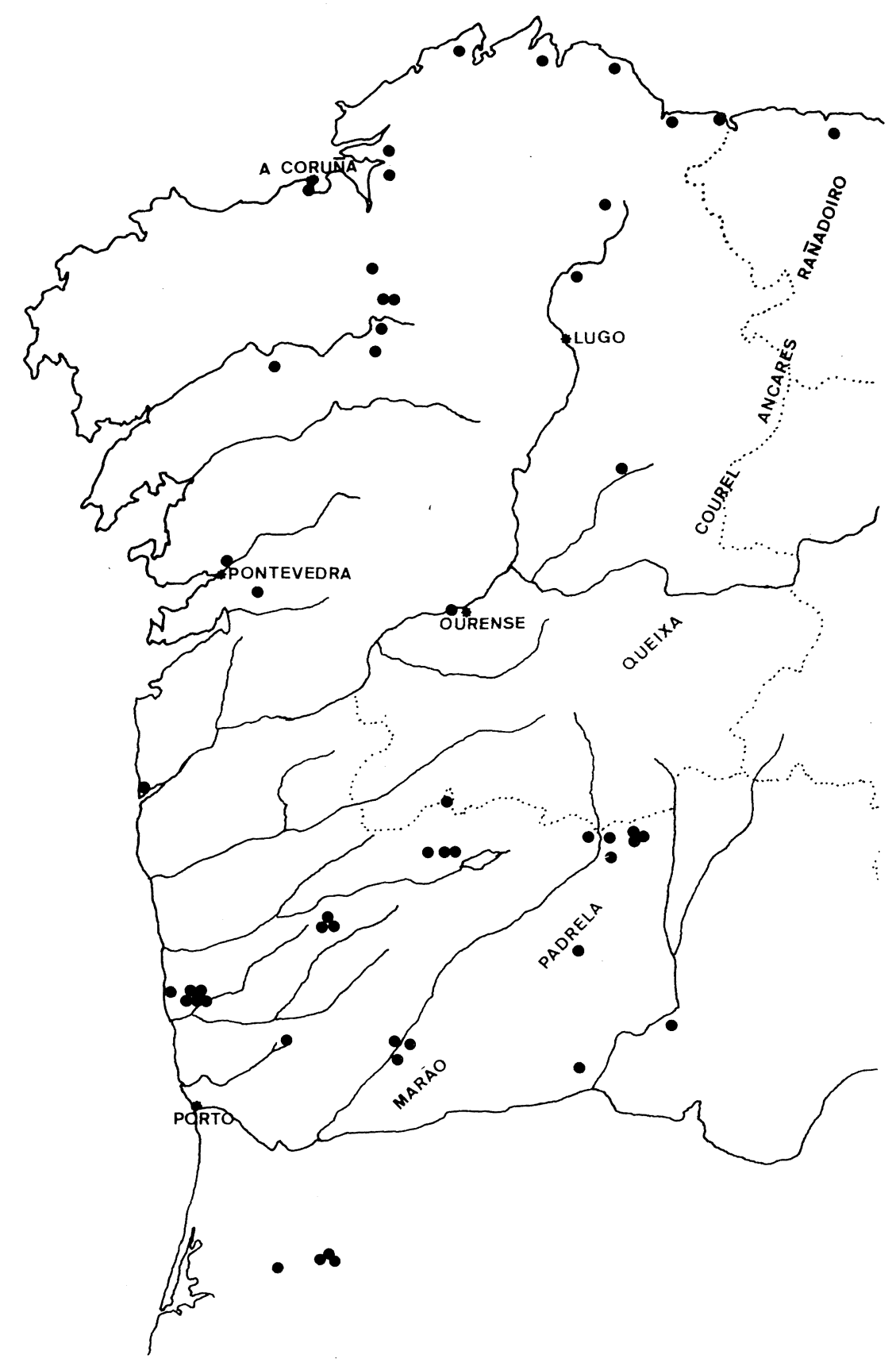

Mapa 3.- Distribución dos torques do NO.

(Sobre mapas de LÓPEZ CUEVILLAS, 1932; TRANOY, 1981 e SILVA, 1986). 


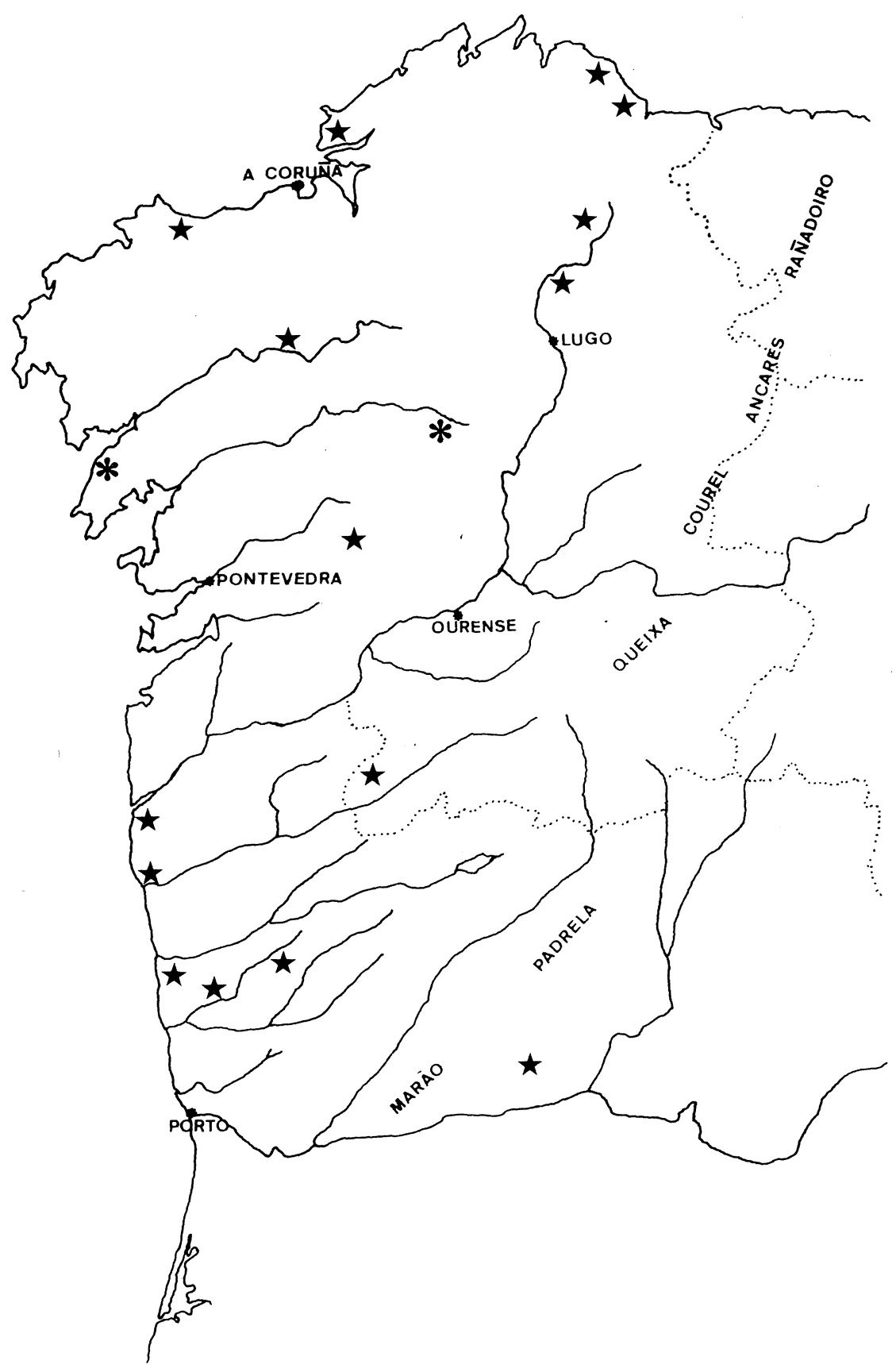

Mapa 4.- Distribución das arracadas castrexas.

(Segundo PÉREZ OUTEIRIÑO, 1982).* Aparecidas posteriormente. 


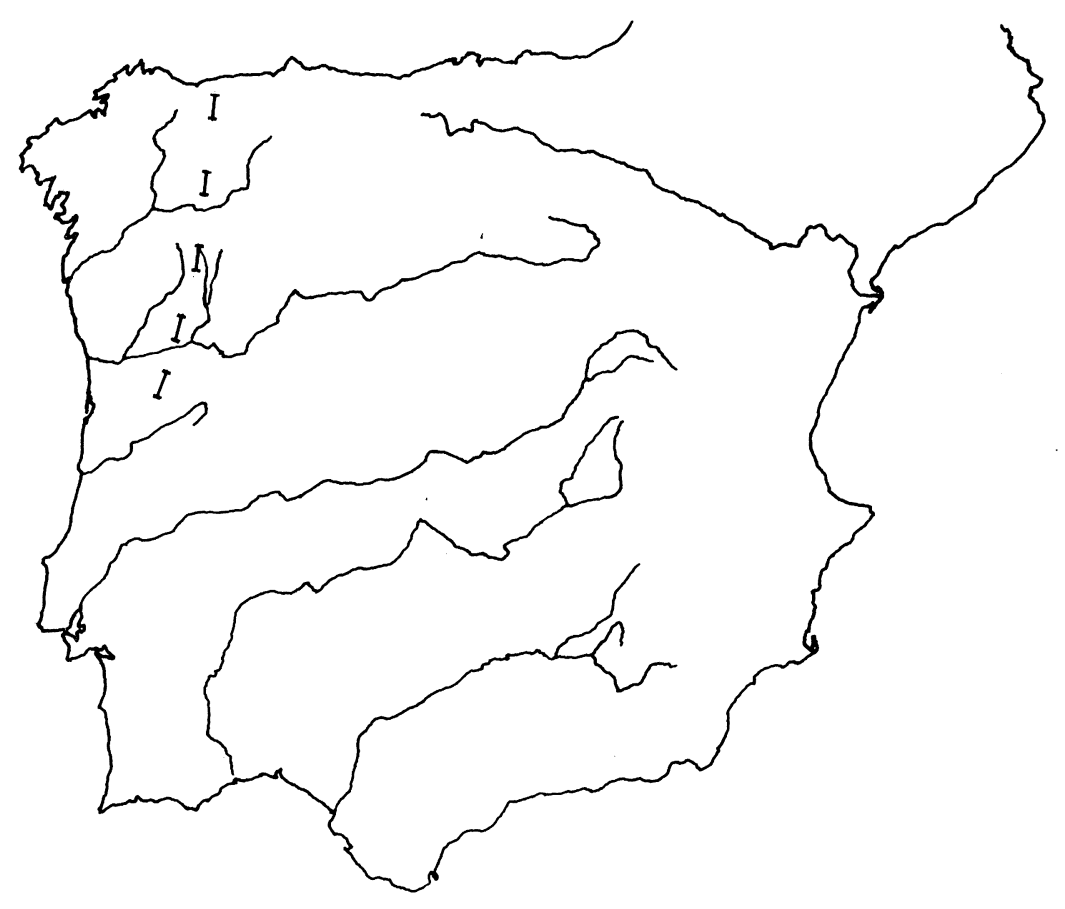

Mapa 5.- Situación da Cultura Castrexa dentro da Península Ibérica. 


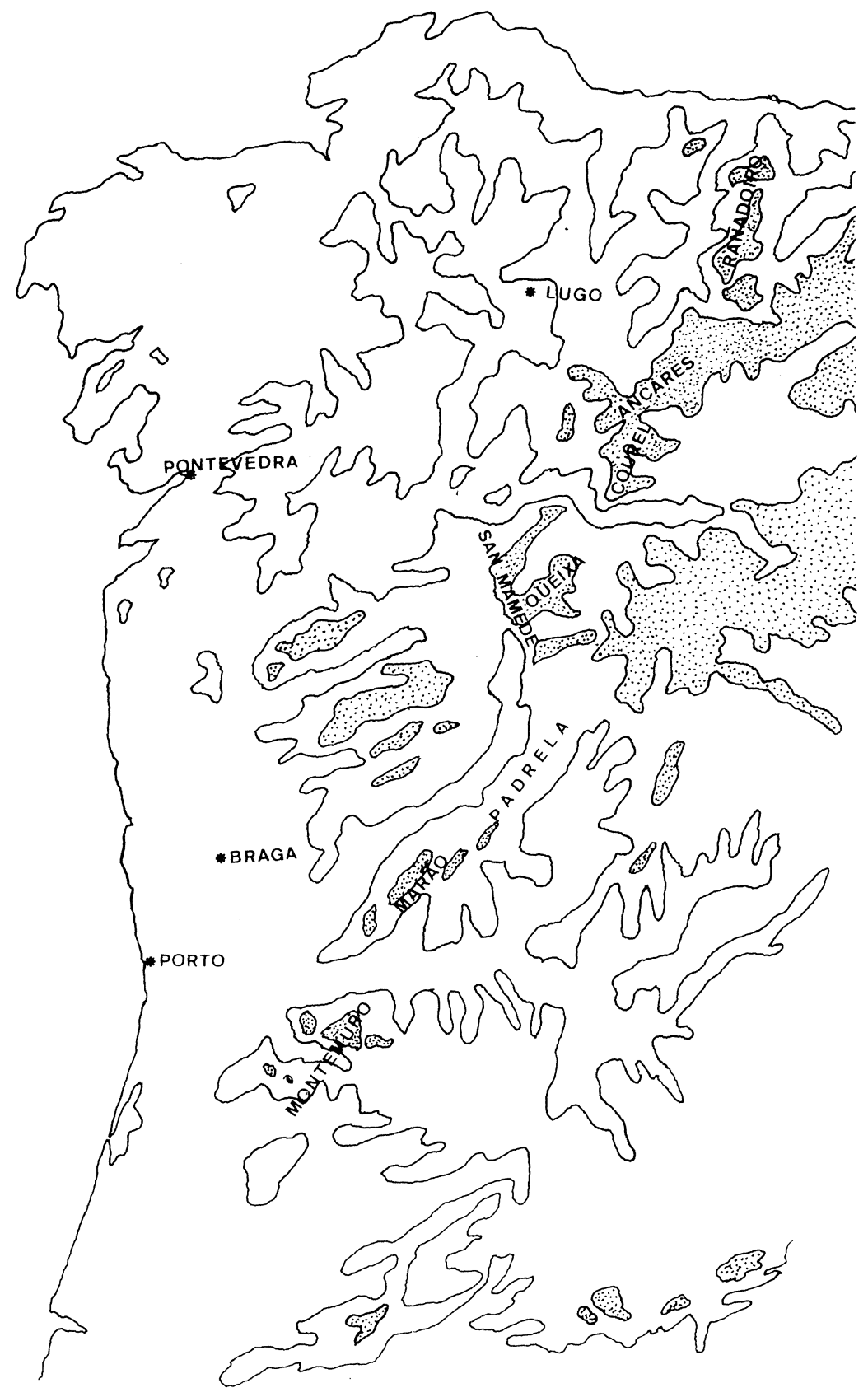

Mapa 6.- Serras divisorias da Cultura Castrexa. Liña: $500 \mathrm{~m}$. Punteado: $1000 \mathrm{~m}$. 
Troña, 87 Vandoma, 88 Vermoim, 89 Vigo, 90 Vilapedre, 91 Vilar, 92 Vilar de Barrio, 93 Vilarelhos, 94 Xesteira, 95 Xinzo de Limia, 96 Midões, 97 Lemenhe, 98 Riba de Mouro, 99 Monte Güimil, 100 Ameixeira, 101 Castro das Eiras. Notarase que os seis últimos non están alfabetizados; por diferentes razóns figuran nun apéndice da miña tese.

Indirectamente, pois non ían por aí as miñas pesquisas, unha vez confeccionado o mapa observei a súa semellanza cos da dispersión de pezas do Bronce Final ou da ourivería castrexa (mapas 2-4), polo que, engadíndolle outros parámetros, non dubidei en propoñer uns límites xeográficos para a Cultura Castrexa moito máis restrictivos que os tradicionalmente citados e que curiosamente veñen coincidir en boa parte cos primeiros que propuxera López Cuevillas (1933), e conseguintemente desbotei os mapas ó uso coas desmesuradas zonas de "hinterland" que por ningures atopei. Tocar esto aquí desviaríanos do tema para o que fun chamado, polo que remito novamente á miña tese (Calo, 1994) ou mesmo ó meu libro (Calo, 1993). Véxanse mapas 5-6.

Parto, pois, da aquí premisa, noutro lugar conclusión de que a plástica castrexa non é anterior á chegada de Roma ó Noroeste. Ben sei que se poden poñer obxecións e no coloquio que siguiu á exposición o profesor Martín Almagro dixo que necesariamente tiña que haber esculturas anteriores. Eu só podo dicir que os historiadores temos que traballar baseándonos na documentación existente. Estou en condición de afirmar que a manexei toda, pero non ignoro que en Arqueoloxía unha nova excavación pode facer modificar presupostos, conclusións e esquemas. Cando nunha excavación fiable, nun contexto definido anterior ó das fins do s. I a.C. apareza unha estatua ou unha decoración arquitectónica, aceptarei a evidencia, e nin me parecerá ben nin mal, pois a ciencia non entende de bondades, e polo mesmo terei que muda-la miña opinión, pero non rectificar, pois antes do microscopio obviamente non se podía falar de neutrinos.

Dito o anterior, pasamos a analisa-las pezas, englobadas nos seguintes grupos: guerreiros, cabezas humanas, cabezas zoomorfas, sedentes, figuras diversas, decoracións arquitectónicas e "pedras formosas".

\section{GUERREIROS}

Ata o presente contamos con 26 exemplares máis ou menos completos ou mutilados, dos que 20 foron atopados en territorio portugués, 5 na provincia de Ourense e 1 na de Pontevedra. Esta sería a relación: 4 Lezenho, 
1 Meixedo, 2 Basto, 2 Monte Mozinho, 1 Vila Verde, 1 Fafe, 1 Vizela, 1/2 Cendufe, 1/2 Sanfins, 2 Armea, 1 Sabanle, 1 Castromao, 1 Britelo, 1 Midões, 1 Vilar de Barrio (os tres últimos desaparecidos), 1 Rubiás, 1 Anllo e 1 Roriz (estes tres son dubidosos — só a cabeza-, pero con moitas probabilidades de seren parte de guerreiros). Na lista dos guerreiros inclúense tamén Castro de Río, Sta. Águeda e Paderne (para min moi dubidosos), así como Guarda, Vilarelhos e Bergazo (moi dubidosos e atopados lonxe dos lindeiros desta estatuaria); se os incluiramos aquí resultarían un total de 32 exemplares.

Non é este o intre de facer unha descripción polo miudo de cada un deles. Digamos tan só que a característica tipolóxica é a de representar un icono de guerreiro en actitude de parada. Hai elementos comúns, caso da caetra, ou pequeno escudo redondo, e existen variantes con respecto ás virias, bazaletes, torques, pés calzos ou nus, couraza e "sagum" decorados ou lisos (probablemente pintados), espada sobre o peito ou non, adicatoria, cinto máis ou menos elaborado, knémidas ou polainas, etc... Podemos dicir que hai un nidio ar de familia en toda esta estatuaria, pero ó tempo vemos diferencias de tratamento, de técnica e de detalles que nos fan pensar, non en escolas, para o que carecemos de datos, pero si en diferentes autores, partindo da base de que se trate, como dixen atrás, de pezas contemporáneas. De feito podo asegurar que en tódolos castros nos que apareceron guerreiros e se fixeron excavacións arqueolóxicas o seu período único ou álxido corresponde ó s. I d.C.

A monumentalidade das estatuas de guerreiros fixo que foran moitos os autores que se ocuparon delas nos seus estudios, anque, como veremos, as opinións xiran repetitivamente ó redor dunhas poucas ideas, sobre todo ata a década dos 80 , na que os avances no coñecemento da Cultura Castrexa fixeron que moitas cousas se poideran matizar ou analisar con datos máis fiables.

Sería o gran epigrafista alemán Hübner (1861: 186 ss.) o primeiro en considera-la estatua de Meixedo, pola súa inscripción, que data nos mediados do s. I d.C., todo o máis nos tempos de Nerón, como funeraria. Engade que tanto na de Meixedo coma na de Rubiás (as dúas con inscripción que se coñecían na época) só aparece o nome do difunto e na primeira tamén a do adicante, polo que "no hay necesidad de suponer que dichos guerreros hubiesen servido en las cohortes romanas" (Cfr. Murguía, 1906: $625)$.

No ano de 1879, nun artigo da Revista Académica, número que non chegou a ser distribuído, Sarmento fai fincapé na cronoloxía das fins do s.

"CUADERNOS DE ESTUDIOS GALLEGOS", Tomo XLI, Fascículo 106, Santiago 1993-94. 


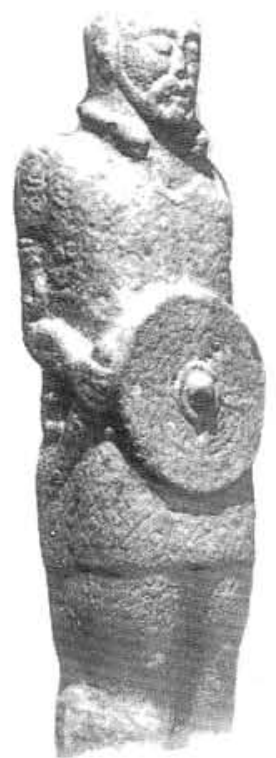

1

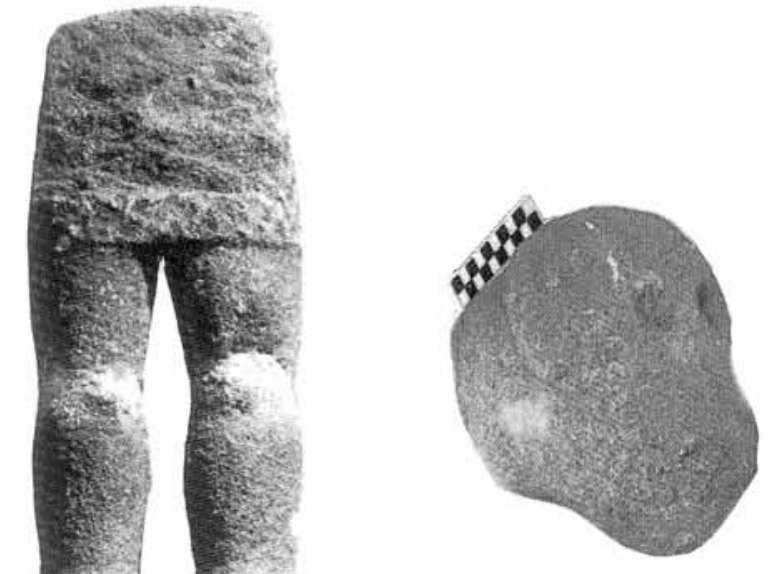

3
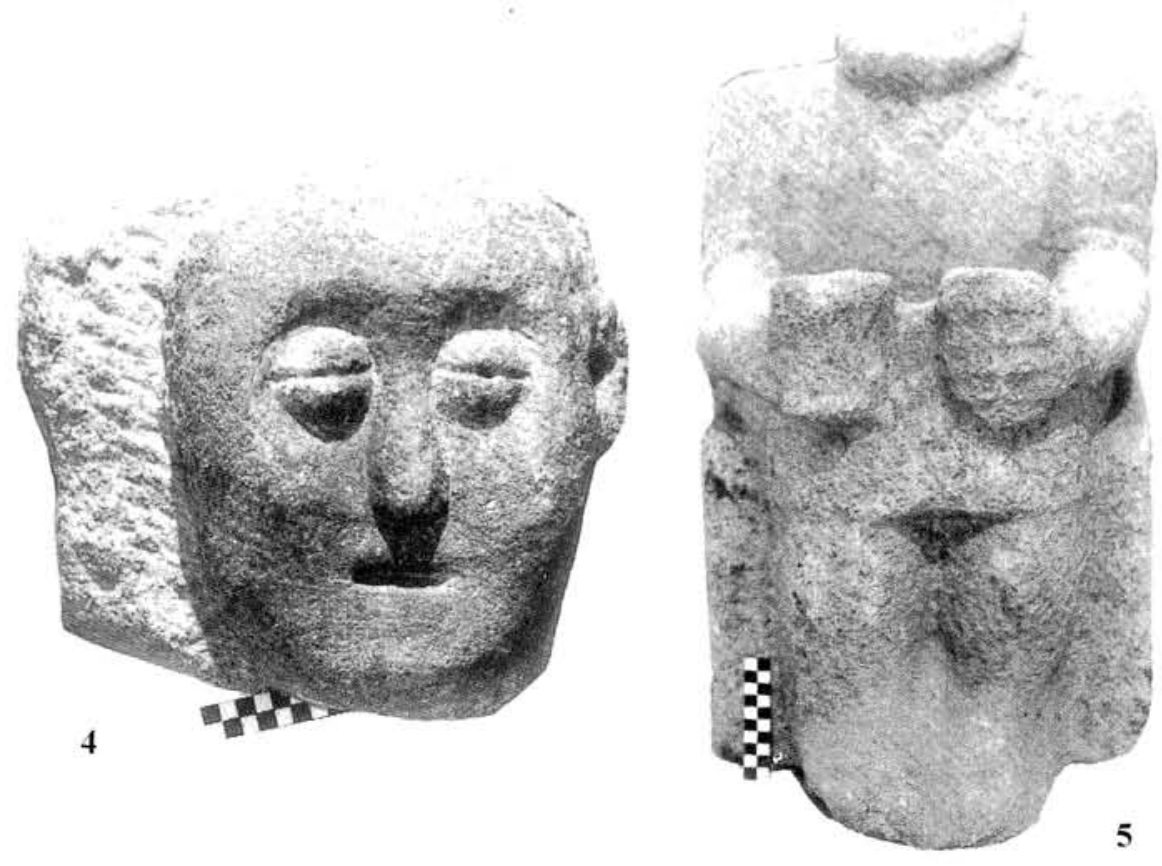

Lámina 1

1.- Guerreiro de Lezenho - 2.- Guerreiro de Monte Mozinho

3.- Zoomorfo de Santa Trega -4.- Cabeza de Armea -5.- Sedente de Xinzo de Limia. 
I d.C. para a inscripción de Meixedo (Sarmento, 1896: 181). Repitirá o mesmo no seu estudio específico sobre a peza (Sarmento, 1881:382) e en carta de 3 de xuño de 1880 a Leite de Vasconcelos dirá que a estatua de Basto "é um resto (pagão) dos antigos genios tutelares das cidades. Os padroeiros representam a Christianização dos mesmos genios" (Cfr. Vasconcelos, 1901:33, nota 4). Pouco despois insiste na cronoloxía "lusoromana" para estes iconos e, seguindo a Hübner, di que é posible que foran funerarias (Sarmento, 1886: 246), idea que comparten Vasconcelos (1896: 32) e Guerra (1899-1900: 175). Para Murguía (1901: 562) serían representacións de guerreiros cumprindo unha función de término, e deixa aberta a hipótese de que algunha peza fose anterior á dominación romana, idea que logo desbotará cando escribe que son dos "primeros tiempos del imperio... sin vacilación de ningún género" (Murguía, 1906: 496, nota 1). O mesmo aceptan Paris (1903a: 71 e 1903b: 1-8), Peixoto (1903:2), Pereira (1908: 213)...

Ata aquí a interpretación principal é a funeraria, se ben Pereira tamén apunta a posibilidade de que se trate de heroes epónimos dun castro, de galaicos ou lusitanos divinizados (Pereira, 1908: 243-244).

Non é cousa de traer aquí toda a bibliografía, pero podemos engadir que durante moitos anos deixou de interesa-lo tema.

López Cuevillas dubidará entre a función funeraria e a honorífica e aínda propoñerá algo novo: serían apotropaias ou espíritus protectores dun lugar (López Cuevillas, 1958: 355). Para Maluquer (1963: 68) serían funerarias ou votivas, e Taboada (1965: 12) opina que as inscripcións deberon de ser feitas con posterioridade ás estatuas, reaproveitándoas; non se define entre a función funeraria, honorífica ou votiva. Blanco Freijeiro compara a metopa do friso dórico en marbre de Porta Flaminia con representación dunha caetra coas que portan as estatuas de Vizela e Cendufe e asegura a cronoloxía dos primeiros anos do Imperio; serían caídos ó servicio de Roma (Blanco, 1971:230-231). Cardozo (1973a: 271) apunta a posibilidade dun culto a xefes notables ou a un deus guerreiro, e no mesmo ano (ID., 1973b: 155) insiste neso, pero -ó contrario de Blancoserían xefes que loitaron contra Roma. Sen falar de bandos, Almeida (1975: 494) pensa tamén en xefes ou guerreiros mortos. Anos despois dirá que son xefes guerreiros heroizados (Almeida, 1981: 115). Unha "função heroizada de tutela" terían para Silva (1981/82: 90), quen precisa que a fórmula F.C. (no segundo guerreiro de Basto) non sería propia dunha divinización.

Voltan sobre o tema Tranoy (1981: 114, 327 e 351), Almeida (1982:

"CUADERNOS DE ESTUdIOS GALlEGOS", Tomo XLI, Fascículo 106, Santiago 1993-94. 
84), Vázquez Varela (1982: 42)... Nós mesmos, no ano 1982, pensabamos que o icono guerreiro "sería o heroe guerreiro... que se levanta frente á plástica heroica ou heroizada romana nun momento de plena romanización" (Calo, 1983: 178). Máis opinións pódense ver en Almeida, Br (1983: 8890), Alarcão (1986: 64-65), ID. (1988: 195-196), Plácido (1989: 294), Tranoy (1988: 223-225), etc.

Sintetizando tódalas interpretacións, razonadas ou miméticas, vemos que todas elas xiran ó redor destas ideas: funeraria, xenios tutelares das cidades, heroes epónimos dos castros, heroes divinizados, apotropaias, votivas, honoríficas, deuses bélicos, consagración de xefes ou guerreiros mortos, heroes galaicos versus e plástica heroica romana, príncipes e heroes locais que loitan nas tropas auxiliares romanas... Con respecto á cronoloxía as opcións son obviamente poucas, pero todas elas véñense barallando do primeiro ó último dos traballos citados: prerromanas (poucos), dos inicios do Imperio (os máis) ou unhas prerromanas e outras imperiais. Pola nosa banda, xa deixamos dito que, cos datos na man, son todas do s. I d.C. Se aceptamos esta cronoloxía, podemos empezar a teorizar.

Na miña opinión a conquista do Noroeste tivo lugar definitivamente na época de César. Se esto, como penso, é así, podemos interpretar unha serie de fenómenos que serían inexplicables se a conquista tivera lugar na secuencia das Guerras Cántabras. Vexamos:

A partir de Augusto presenciámo-lo reforzamento das murallas castrexas, fanse "ex novo" potentes castros como Monte Mozinho, San Cibrán de Las e tantos outros, benefícianse urbanísticamente, aumenta o nivel de vida (como están a indica-los materiais), érguense murallas, embellécense as casas.. e os seus habitantes teñen clara conciencia e posiblemente sinten orgullo de pertencer ós mesmos, o que se manifesta no signo ")" das inscripcións, e, por suposto, escúlpense as estatuas de guerreiros. Nada desto tería lóxica se o NO. viñera de ser conquistado por Augusto. A Historia repítenos constantemente exemplos de que cando un pobo ocupa a outro excesivamente hostil ou perigoso procura evitar toda posibilidade de reorganización do mesmo, esnaquizando as súas defensas, facendo levas de poboación, ridiculizando ou aplicando a "damnatio memoriae" ós seus heroes, etc... A táctica de Roma semella ter sido aquí moi diferente, polo que podemos pensar que este territorio non presentaba preocupacións ó invasor, e por tanto resultaba máis positivo deixar facer e mesmo potenciar certas manifestacións para sibilinamente ir controlando e aculturando cada vez con máis intensidade a estes pobos. E nestas circunstancias aparecen indefectiblemente os colaboracionistas.

"CUADERNOS DE ESTUdiOS GALLEGOS", Tomo XLI, Fascículo 106, Santiago 1993-94. 
Non é difícil pensar que algunhas familias dos castros, chámense os cabos da casa Camalus (petrucio dunha familia de oleiros de Briteiros), Verotus, Corocaucus ou Dovilo... (por cita-los que figuran nos epígrafes das estatuas) se fixeran colaboradores ou "amigos" dos romanos, e que estes os potenciaran diante dos seus conveciños. É a historia de sempre: o colaboracionista medra en prestixio e autoridade co apoio do ocupante e este emprégao como elemento propagandístico.

Eu penso que as estatuas de guerreiros galaicos se ergueron, porque Roma quixo, a aqueles notables dos castros que colaboraban con ela. Por eso non é extraño que nas fins do s. I se deixen de facer, do mesmo xeito que o ")" da paso a novas fórmulas para sinala-lo "origo". Despois da doazón do "Ius Latii" a indicación do castelo desaparece (Pereira Menaut, 1980: 29, nota 8). Roma conseguira o que se propuxera.

Por razóns de espacio non podemos traer aquí a argumentación, pero penso que as estatuas de guerreiros eran verdadeiras obras públicas costeadas por particulares, que deste xeito estarían a facer unha inversión económica non improductiva, senón que se trataría dun gasto suntuario que formaría parte do que Wolf (1982: 16-18) chamaba "fondo ceremonial". Noutras palabras, facíase un desembolso importante que redundaría no prestixio social que esa familia ía adquirindo dentro do seu propio castro. Trataríase do vello ou novo grupo social que estaba a destacar nos poboados baixo a "tutela" de Roma.

\section{CABEZAS HUMANAS}

Espalladas pola actual Galicia e algunhas tamén en territorio portugués foron aparecendo unha serie de cabezas humanas en pedra que, sen crítica algunha, se incluíron na plástica castrexa. Eu traballei sobre 23 exemplares: 2 de Barán, 3 de Armea, 2 de Cortes, 1 de Narla, 1 de Moreira Nova, 1 de Remesar, 2 de Gaxate, 1 de Chaves, 1 de Sta. Iria, 1 de Monte Mozinho, 1 de Três Minas, 1 de S. Cibrán de Las, 1 de Ocastro, 1 cecais de Torres de Oeste, 1 posible bifronte de Francos, senllos bifrontes en Óutara e Amorín e o cuadrifronte de Pontedeume. No proceso de redacción da miña tese apareceu - e foi citada - a cabeza de Monte Güimil e posteriormente tiven coñecemento doutras de recente aparición que non cito por respeto ós dereitos dos seus achadores. Algunhas das pezas estudiadas, caso da de Óutara, desboteina, con argumentos que non son ó caso agora, da plástica castrexa.

"CUADERNOS DE ESTUDIOS GALLEGOS", Tomo XLI, Fascículo 106, Santiago 1993-94. 
De todas elas únicamente a de Monte Mozinho e a de S. Cibrán de Las foron atopadas no decurso dunha excavación, e dentro dun castro, de xeito fortuíto ou por mor de obras de explanación, apareceron as de Ocastro, Barán, unha das de Armea, outra das de Cortes, Sta. Iria, Francos e Monte Güimil. As restantes saíron de muros, cortes, tellados, etc., polo que a súa filiación castrexa, baseada na tosquedade e na proximidade dun castro, non é máis ca unha suposición.

Malia ter sido atopada e doada a Sarmento a de Sta. Iria no ano 1876, haberá que agardar moitos anos para ve-las cabezas tratadas na bibliografía. En 1932 atopa Vázquez Seijas as dúas de Barán e en 1934 aparece a primeira, e conservada, de Cortes. Aquel autor considera ás primeiras "imágenes idolátricas" (Vázquez Seijas, 1933: 126). No traballo de Taracena (1943: 157-171) sobre catro cráneos atopados en Numancia, que o fan pensar na "conservación aislada de los cráneos" e enlazar con "La agria costumbre gala de utilizar como trofeo la cabeza cortada del enemigo vencido...", menciona as cabezas de Sta. Iria, Barán e Cortes "de tiempo impreciso, pero ya de romanización...". Considéraas de proxenie céltica e di que poden aludir "a la práctica de las cabezas-trofeo".

Conde-Valvís atopa dúas cabezas empotradas nun palleiro do lugar de Abeledo, perto do castro de Armea, e envía unha foto a Benoit, quen a publicará chamando ás pezas "têtes coupées" e emparentándoas coas de Entremont, Bringasses (Les Baux) e a torre de S. Magín en Tarragona (Benoit, 1949: 243-255). Este autor tentou sempre demostrar que o tema de cabeza humana é propio e común a todo o Mediterráneo, polo que resulta incomprensible que, partindo da súa autoridade, as cabezas castrexas se convirtan nun elemento clave para asegura-la celticidade do NO, cando Benoit sempre se esforzou por demostra-lo contrario para o Midi.

Para López Cuevillas trátase de "têtes coupées" e lémbranlle positivos de mascariñas funerarias (López Cuevillas, 1951: 195-196). Conde-Valvís coida que son "imagenes" ou retratos de difuntos, como facían os romanos "quienes muy bien pudieron haber difundido esta práctica entre los indígenas". Non dubida en encadralas en época romana (Conde-Valvís, 1950-51: 87-88). No mesmo ano publica Bouza a de Ocastro e considera a todas elas apotropaias, introducindo o apriorismo do celtismo para estas pezas (Bouza, 1951: 33-42).

En 1956 publica Blanco a cabeza de Narla. Abandona a tese das cabezas cortadas e das do NO. di que o único que sabemos é que "son obras catreñas" e inclínase pola posibilidade de que sexan representacións de deuses (Blanco, 1956: 159-180). Para Blázquez (1960: 217-226) trátase 
de máscaras humanas con carácter decorativo.

Outros autores, como Balil, Sayáns, García Martínez, Acuña e Cavada, Luzón, Guitart, etc. publicarán novas pezas, e Taboada (1965) non dubida en afirma-la celticidade do que para el son cabezas-trofeo ou "têtes coupées" e divide toda a estatuaria castrexa en céltica e romana de abolengo céltico.

A partir destas datas aparecerán e serán publicadas cabezas por toda a Península, desde Lleida a Asturias, Andalucía, Extremadura, Zamora... Curiosamente, en bastantes casos escoménzase dicindo que se atoparon en construccións medievais e posteriores, para logo argumentar que se asemellan ás castrexas "de probada celticidade" polo que pasan a engrosala nómina das pezas célticas.

Tódalas teorías redúcense a "têtes coupées", cabezas-trofeo, positivos de mascariñas funerarias, deidades, deuses sen corpo, exaltación da cabe$\mathrm{za}$, "imagenes" ou retratos funerarios e, as de varias caras, hérmatas.

Eu penso que o tema das cabezas castrexas foi excesivamente magnificado, que foron estudiadas entroncándoas cun ambiente cultural moi distinto e distante para finalmente ser tomadas como paradigma para a interpretación de toda canta cabeza humana aparecía, descontextualizada ou non, na Península Ibérica. Retomémo-lo tema.

Citabamos ó primeiro as cabezas atopadas nun castro, e foron precisamente as descontextualizadas, xunto coa de Ocastro achada casualmente, as que deron lugar a tódalas teorías e as que serviron de comparación para as restantes da Península. Podo dicir que as cabezas "certas" aparecen en castros ben romanizados, ou mesmo, caso de Três Minas, nun ambiente mineiro romano. Segundo esto, toda a literatura sobre "têtes coupées" e a arte céltica de pouco nos serve e as teorías sobre prerromanismo carecen hoxe de fundamento.

Busquemos paralelos neste novo contexto cronolóxico-cultural.

Cabezas idénticas ás nosas atopámolas en Tarentum, en Baelo, en Hofheim, nas Fontes do Sena..., todas elas perfectamente datadas no s. I d.C. Desde o punto de vista estilístico, todas, xa sexan da Bética, de Alemania, de Francia ou da propia Italia, teñen en común a sinxeleza e economía de rasgos e, se as de Tarentum e Baelo Claudia son con certeza representacións de difuntos "sub imagine", independentemente de que as consideremos retratos "de tipos", "intencionais", "alusións icónicas" ou "símbolos do morto", por seguir a Balil (1974, 107-108), as castrexas, coincidentes en cronoloxía e estilo, entramentras non se atope unha "in situ" que demostre o contrario, cumplirían unha función semellante. Hoxe 
podemos dicir que no s. I d.C. o Noroeste forma parte dunha "koiné" artística mediterránea-romana. Por conseguinte, falar de escultura céltica prerromana e de escultura romana de abolengo céltico para referirnos, por exemplo, ás estelas do s. III, non se sostén. O camiño vai máis ben polo de "arte patricia / arte plebeia", arte para "gentes e incolae"..., seguindo a terminoloxía de Bianchi e Balil ou mesmo "arte de Galicia en época romana" como algúns temos apuntado noutro lugar. Pero novamente o límite de páxinas impide desenrola-la cuestión.

\section{CABEZAS ZOOMORFAS}

A diferencia das demáis manifestacións plásticas da Cultura Castrexa, as cabezas de animais, cecais por escasas e/ou por excesivamente informes, non suscitaron un gran interés entre os investigadores. Voume referir tan só a cabezas, tendo en consideración que a única peza de corpo enteiro que, dentro dos lindeiros do castrexo, foi publicada, a de Sta. Marinha de Zêzere, foi descuberta totalmente descontextualizada e non ten relación de ningún xénero - anque en ocasións se dixo o contrario - cos coñecidos "berrões" trasmontanos. Concordo con Vasconcelos e Sarmento para quen non era máis ca un "mono" ou "mostrengo", respectivamente.

Teño referencias dunha peza en Paderne, dúas en Sabroso, tres ou catro en Sta. Trega, unha en Armea, Florderrei Vello, Cabanca, cecais en Troña e outra en Ameixeira. Xa fóra dos límites e feita cunha técnica totalmente distinta das restantes estaría a de Eirexario ou Vila de Sen. En canto ás de Florderrei Vello e Cabanca, xusto nos lindeiros da Cultura Castrexa, teño que dicir que desapareceron hai moitos anos, polo que só temos refrencias literarias das mesmas. Non inclúo na relación a "cabeza de ovella" de Sanfins por tratarse de pura invención ou fantasía.

Vexamos moi brevemente a representación de cada unha delas. A de Paderne ten aspecto de súido; unha de Sabroso pode ser boi, porco ou ovella, a outra é sen dúbida un fuciño de porco; das tres ou catro de Sta. Trega díxose se serían bois, cans, aves, ofidios, cápridos..., segundo os diferentes autores. A de Armea foi considerada cabeza de carneiro. Da de Florderrei Vello nin siquera sabemos se era de corpo enteiro e a de Cabanca disque era unha cabeza de xabarín.

Vemos, pois, que o repertorio é tan cativo e malo que nos máis dos casos nin se pode aprecia-la especie animal que representa.

Os poucos autores que se ocuparon desta plástica puxérona en relación

"CUADERNOS DE eStUdios GALLEGOS", Tomo XLI, Fascículo 106, Santiago 1993-94. 
cos "verracos" ou "berrões" meseteños e trasmontanos, e consecuentemente adxudicáronlle unha función semellante. Entre os galegos temos que destaca-la figura de Taboada para quen estas estatuas respostarían a cultos apotropaicos de pobos gandeiros influídos pola celtiberia (Taboada, 1946: 42), ou ben ídolos defensores das casas, con cronoloxía moi posterior á das pezas da Meseta (Taboada, 1948: 291-292), afinando a cronoloxía, que leva a época romana en Taboada (1949: 18-19).

Se en Galicia temos a Taboada, en Portugal o máximo especialista será Santos Junior, autor dunha ducia de títulos sobre o tema, dos que suliñamos Junior (1975), por compendiar tódolos anteriores, e Junior (1985: 31-40) por se-lo último que lle coñezo e no que volta a insistir que os "berrões" son a manifestación dun culto zoolátrico, animais sagrados que se adoraban como deuses tutelares.

Para López Monteagudo, estudiosa da totalidade dos "verracos" peninsulares, uns hai que poñelos en relación cun contexto funerario, outros terían que ver con santuarios dunha divinidade de carácter psicopompo e ctónico que asimila a Marte... ocupando un marco temporal entre o s. VI a.C. e o III d.C. e situando en plena romanización os que a nós nos ocupan (López Monteagudo, 1989). É mágoa que esta autora incluíra as nosas pezas, sen crítica, dentro do conxunto.

Para min, querer incardinar ou mesmo relaciona-las pezas galaicas coa "Cultura de los verracos" carece de fundamento, polo que xa desde agora desboto a clasificación apriorística e indiscutida de "verracos" de corpo enteiro (Meseta-Tras-os-Montes) e cabezas soltas (Sur de Galicia) formando parte dun todo. En realidade o que temos é o seguinte: cabezas de porcos seguras, en territorio plenamente castrexo, hai unha en Paderne e outra en Sabroso, e no límite do castrexo (segundo referencias bibliográficas) en Florderrei Vello e Cabanca, e xa fóra do castrexo e dunha calidade excepcionalmente superior a tódalas pezas da cultura dos "berrões" a de Eirexario; dous posibles ofidios aproveitando a forma duns amarradoiros, e o resto poden ser cans, cabras, touros ou ovellas. ¿Cultura dos "verracos", das ovellas, dos touros ou dos cans?. Por outra banda, as nosas pezas conservadas enteiras son todas elas para empotrar nun muro, o mesmo que sucede cos couzóns, amarradoiros e tantos motivos decorativos, o que nos está a falar dunha concepción diferente da plástica. É moi distinto atopar un "verraco" ou touro, con ou sen plinto, con ou sen inscripción, nun recinto funerario ou relixioso que unha cabeza de "animal indeterminado" descontextualizada, agás a de Paderne que estaba empotrada nun muro dunha construcción circular do mesmo xeito que tantos amarradoiros

"CUAdERNOS DE ESTUdios GALLEGOS", Tomo XLI, Fascículo 106, Santiago 1993-94. 
atopados "in situ" en recintos que se sospeita eran cortes de gando.

A Cultura Castrexa da zona sur, a diferencia da dos "berrões", amosa un enorme interés polo decorativismo arquitectónico e aí encaixan estas pezas con representación animalística. ¿Cumplirían algunha outra función?. O máis doado é dicir que, se realmente se colocaron todas en recintos pecuarios, poderían ter un valor profiláctico ou apotropaico, pero realmente ningún indicio me permite argumentar eso. Se estas esculturas cumplían ou non un papel protector do gando non o sabemos e, entramentras non se atope algunha figura zoomorfa castrexa "in situ" no proceso dunha excavación, todo canto se diga da súa función non é máis que especulación pura, e cecais só se tratara dunha variante zoomorfa, decorativa, dos amarradoiros dos que falarei máis adiante.

\section{SEDENTES}

No conxunto da estatuaria castrexa contamos con tres pezas que teñen en común representar outras tantas figuras de vulto redondo, sentadas nunhas cadeiras de feitura semellante na forma, e que foron atopadas na sub-área sur ou Convento de Braga. As tres chegaron a nós sen cabeza, o que ven dificulta-la interpretación.

A primeira, coñecida desde hai máis de medio século, procede do castro de Lanhoso, onde foi atopada "a certa distancia das primitivas casas". As outras dúas apareceron xuntas en Xinzo de Limia, son moi semellantes entre si, de tamaño moi superior á anterior e labradas con máis minuciosidade e coidado dos detalles.

A de Lanhoso foi dada a coñecer por Teixeira (1940) e incluída por López Cuevillas nos seus traballos, anque cun certo reparo (López Cuevillas, 1951: 189-190 e ID, 1953: 372-373). Que eu saiba, faise o silencio sobre esta peza; ós investigadores portugueses semella non interesarlles ou cecais, por non ter ingresado en ningún museo, pasou ó esquecemento.

En 1972 coñécense as dúas pezas de Xinzo e inmediatamente relaciónanse coa anterior e suxírese que se trata de representacións "de ciertas divinidades o de personajes que honran de este modo a un numen, no sabemos si del panteón indígena o del romano" (Ferro, 1972: 335). Máis adiante, este arqueólogo excavará o lugar tentando, sen éxito, atopalas cabezas das estatuas (Ferro-Lorenzo, 1976: 354).

Ó ano seguinte, Rodríguez Colmenero dirá que unha das pezas de Xinzo,

"CUADERNOS DE ESTUDIOS GALLEGOS", Tomo XLI, Fascículo 106, Santiago 1993-94. 
a que porta senllos vasos nas mans, é masculina, sendo a outra, a que leva unha especie de pátera, feminina. Compáraas coas "deusas-nais" e, a suxerencia de Blanco Frejeiro, engade que poden ser retratos oferentes dun home e dunha muller ou tamén ter analoxías coas divinidades sedentes da área ibérica (Rodríguez Colmenero, 1977: 325-326).

Nun artigo en colaboración opinamos que as tres pezas poderían ter un carácter funerario, e relacionabámolas con algunhas estelas hispano-romanas e con influencias do Sur (Dama de Baza e similares), pero sobre todo con representacións das Matres (Fariña-Calo-Acuña, P., s/d: 123124).

Para Acuña, anque apareceron nun contexto romano, hai que relacionalas con obras semellantes da Magna Grecia e do mundo ibérico, chegando aquí por influencia meridional (Acuña, 1980: 63). Tranoy segue a Rodríguez Colmenero e di que o único que ten claro e que, polo contexto romano en que apareceron, serían veneradas - a idea esencial do autor é que está diante dun santuario- aínda despois da conquista romana (Tranoy, 1981: 286). Para Silva as tres pezas son femininas e respostan a un panteón non indoeuropeo, senón mediterráneo, vendo nelas unha conxunción do culto funerario co da "terra-mai" (Silva, 1986: 298).

Voltemos ó principio. A peza de Lanhoso apareceu sen contexto, pero a uns $50 \mathrm{~m}$. das casas do poboado e aprécianse restos doutras a ámbolos lados. Non sabemos, pois, se estaba dentro ou fóra do recinto habitacional. Que o castro foi moi romanizado, amais da ergoloxía, próbao unha sepultura romana de tégulas aparecida entre dúas casas redondas.

As dúas de Xinzo, segundo o excavador, estaban nun recinto que pertencería a unha vila e apareceron xunto con tégulas, ímbrices, ladrillos, un miliario de Galieno Valerio Maximiano (morto en 311) e cerámica de "muy baja época". Posteriormente atopouse sigillata e unha ara, cecais do s. I d.C.

Con estes datos podemos pensar que se trata de obras feitas en época romana, pero a cronoloxía tanto nos pode levar ó s. I como o s. IV.

Non podemos entrar agora en detalles, pero si esquematiza-lo seguinte: As tres estatuas pertencen á mesma familia e posiblemente resposten á mesma idea; non hai razóns para pensar que todas elas ou algunha sexan femininas; os vestidos das de Xinzo son idénticos ós dos guerreiros castrexos (colo en "V", liña vertical a xeito de couraza, mangas por debaixo dos ombros, virias, unha con torques, etc.). Eu coido que se trata de tres iconos masculinos, pois non hai unha soa representación feminina que teña tales atributos.

"CUADERNOS DE ESTUdiOS GALLEGOS", Tomo XLI, Fasciculo 106, Santiago 1993-94. 
Con respecto á interpretación, ó significado, só podemos aventurar hipóteses. Non hai dúbida de que a idea é mediterránea; hoxe non acredito que se trate de matres, cando en Monte Mozinho hai unha boa representación delas moi diferente das que nos ocupan; as tres son de época romana (s. I-IV d.C.); a de Lanhoso ten un oco na base que só ten senso se pensamos que serviría para conter cinzas (lembrémo-la plástica ibérica). Se ben as de Xinzo carecen del, as similitudes coa anterior fanme pensar nunha función funeraria semellante.

Con respecto á cronoloxía, lembremos que a cremación dou paso á inhumación ṇos inicios do s. II d.C. e, se en Lanhoso houbo, como sabemos, unha forte ocupación en época augústea, e a sepultura de tégulas antes citada se fixo nunha fase de reaproveitamento do espacio do castro, non repugna asignar á nosa estatua unha cronoloxía do s. I d.C. Das de Xinzo dixen que están vestidas como os guerreiros castrexos e, se estes se deixaron de facer en época flavia, penso que atribuirlles unha cronoloxía posterior, ata o s. IV, sería un anacronismo sen senso. É lóxico pensar que guerreiros e sedentes son coetáneos, e dicir, de época Xulio-Claudia.

O punto realmente oscuro segue a ser o porque unha idea mediterránea chega aquí, con retraso e sen pasos intermedios coñecidos, e sobre todo a razón de que, como penso, sexan homes e non mulleres, como era habitual - non sempre - no Sur, o que cecais se debe á peculiar estructura da sociedade castrexa no seu punto álxido, que os romanos souberon aproveitar e/ou potenciar.

\section{FIGURAS DIVERSAS}

Cada vez son máis as pezas que representan figuras humanas, ou partes anatómicas das mesmas, de moi diferente concepción, feitura e cecais cronoloxía, que están a aparecer nos nosos castros. Fagamos unha relación: sedente de Briteiros, relevo con dúas figuras do mesmo castro, parte inferior da estatua de Zêzere, catro iconos de Sta. Trega, figura feminina de Sendim, estatua de Vilapedre, estatua de Genço, estatuiña de Carabeles, dúas figuras de Logrosa, relevo de Lanhoso, relevo de A Igrexa (Lourizán), torso de Monte Redondo, figura fálica de Elviña, falos de Elviña, Monte Mozinho e Troña e pés de Bergazo.

Obviamente, na miña exposición só me foi posible, por razóns de tempo, enunciar este apartado. Agora, por mor do espacio dispoñible e por se-lo máis fiel ó dito no seu día, tampouco entrarei en materia, pois tería que 
estudiar peza a peza. Direi tan só que nalgunhas, malia as diferencias, hai puntos en común, por exemplo a colocación dos brazos e mans sobre o peito ou ventre que vemos na sedente de Briteiros, nunha de Sta. Trega, nas dúas de Logrosa, na de Carabeles e na de Sendim. Esta última muller sen cabeza, preñada, coas pernas e o sexo aberto e esaxerado foi interpretada como "deusa-mai" (Silva, 1986: 298); no seu lugar indiquei a posibilidade de que se tratara dun exvoto do tipo do "tolleito" do Museo Arqueolóxico Nacional de Lisboa adicado a Endovélico e de feitura semellante. Tamén apuntei que a estatua de Vilapedre fora outro exvoto, despois de relacionalo con cousas máis ou menos semellantes do santuario do Sena, e o mesmo fixen coa peza de Carabeles (Urdilde).

Con respecto á de A Igrexa (Lourizán), coñecida como "Vestio Alonieco" polas dúas aras aparecidas a pouca distancia da peza, seguindo o traballo de Benoit (1959) concluín considerándoa un Mercurio ctónico, psicopompo, tantas veces representado nos medios europeos romanizados.

\section{DECORACIÓNS ARQUITECTÓNICAS}

No seu día estudiei case 500 pezas decoradas que obran medidas, fotografiadas e descritas no inventario da miña tese. Podo dicir que a decoración arquitectónica se atopa nuns cantos elementos agrupables en ombreiras e padieiras, é dicir, nos vanos, as únicas partes arquitectónica-mente nobles nun edificio circular, en frisos e nos chamados amarradoiros, couzóns e remates circulares. As "pedras formosas" veranse no apartado seguinte.

Chamo amarradoiros ás pezas cunha parte destinada a empotrar no muro, flexionando a que queda á vista en ángulo preferentemente obtuso. Tense dito que, pola forma de corno, terían unha simboloxía de tipo fálico e mesmo se puxeron en relación cos "cornicula" de Pompeia (Rivas, 1985: 95-96). Eu non lle vexo máis ca unha función práctica, e aínda hoxe hai pedras semellantes destinadas a amarra-lo gando (Cfr. Oliveira et alii, 1988: 97). Tamén é moi posible que algúns foran empregados como percheiros.

Os couzóns, chamados tamén "prisões de gado", son os rematados en forma circular ou oblonga. Chámolle couzóns por estar acuñada a palabra na literatura arqueolóxica, pero coido que é a menos axeitada polo que vou a expoñer. Uns teñen un furo que os atravesa, outros un inicio del ou coviña e un terceiro grupo son lisos e macizos. Estas últimas pezas poderían servir de pousadoiros, como aínda hoxe podemos ver nas portas dos nosos muíños, ou, as pequenas, soportes de lucerna, o mesmo que pensamos das

"CUADERNOS DE ESTUdiOS GALLEGOS", Tomo XLI, Fascículo 106, Santiago 1993-94. 
que teñen coviña, co que a cerámica estaría máis segura. Algunhas son sen dúbida estelas discoideas que nada teñen que ver coa Cultura Castrexa.

Xa por último temo-las pezas completamente atravesadas por un furo. Nos castros teñen aparecido gran número de soleiras e lumieiras (menos, pois ó ser necesariamente máis grandes serían sustituídas -igual ca hoxepor madeira); sempre que estas pezas chegaron a nós enteiras, vemos que teñen os furos dos gonzos da porta, o que resulta máis lóxico, cómodo e económico que empregar pezas do tipo das que estamos estudiando. En moitos casos, os "couzóns" teñen o furo circular nos extremos e cadrado ou rectangular no interior da peza, o que nos está a indicar diferentes funcións: amarradoiros os de furo circular continuo (Cfr. Peixoto, 190508: 78-79) e soportes, alzadeiros, cancelas, ¿teares?, etc. os segundos, polo que necesariamente irían colocados por parellas, como aínda teño visto en portos de mar para pendura-las redes do pao colocado entre eles.

Os remates circulares coa cara externa decorada e sempre destacada do paramento tanto poderían ter unha función ornamental como ser unha variante dos amarradoiros.

Resumámo-las interpretacións que os motivos decorativos suscitaron entre os investigadores. Non podo desenrolalas aquí polo miudo, tendo presente a gran cantidade de bibliografía dispersa que xalundes recollín e sistematicei. Un bo compendio das diferentes teorías témolo en Silva, M. (1986: 59-60), coa salvedade de que eu non concordo coa apreciación que, en nota 16, fai sobre a miña hipótese expresada en Calo (1983: 167).

Martins Sarmento non dubida en afirmar que os antecedentes da gramática decorativa castrexa están no Exeo, concretamente en Micenas (morreu antes de que escomenzaran as excavacións de Creta), e os temas perduran ata despois de Roma (Cfr. Sarmento, 1879a: 157; ID., 1882: 1-2, 19-21 e 26-27 e ID., 1899). Autores como Deonna (1929: 172), Paris (1903a: 33), etc. ... seguirán esta teoría; outros dirán que son pezas suevas e visigodas (Martín, 1881: 160-161) anque logo cambie de idea e llelas adxudique ós celtas. Para Höck (1984: 389-405) son romanas, pero deixa aberta a hipótese de que poidan ser medievais. Déchelette (1909: 25-36) e Bosch (1921: 287) e ID. (1945: 135 e ss.) ven a decoración castrexa unha manifestación, e mesmo tardía, da arte romana. López Cuevillas (1953) fará sempre fincapé no celtismo da cultura e consecuentemente da plástica.

"CUADERNOS DE ESTUdiOS GALLEGOS", Tomo XLI, Fascículo 106, Santiago 1993-94. 
Non imos seguir coa relación. Sintetizando, pódese dicir que as principais teorías, sen apoiatura cronolóxica, sobre o orixe desta decoración son as seguintes: micénica (Exeo), romana e celta, máis a hipótese de que sexan obras suevo-visigodas.

Hoxe sabemos que a decoración castrexa, o mesmo que o resto da plástica ten unha cronoloxía Xulio-Claudia, e a súa dispersión circunscríbese ó Convento Bracarense. Non entro aquí nalgunha peza atopada fóra de Galicia con cronoloxía lixeiramente posterior á das nosas. Tampouco me vou deter nas decoracións das espadas meseteñas e de Alcácer-do-Sal das que se dixo "...que la estética y el espíritu de sus decoraciones se inspira más todavía que en los esquemas de La Tène europea en otros modelos de origen mediterráneo-oriental" (Cabré-Morán, 1979: 768). No NO. contamos tamén cunha ourivería e unhas sítulas con decoracións similares ás da pedra ás que tamén desde os traballos de Blanco Freijeiro se vencellou con temas do Sur.

Eu non dubido de que a decoración castrexa procede do Mediterráneo, ó igual que sucede coa arte latènica dos galos dos que se chegou a dicir que acolleron con "tal frenesí" os costumes greco-romanos que chegaron a esquece-lo pouco que sabían facer antes (Thévenot, 1972: 71). O Mediterráneo espoleará ós habitantes do Midi francés e o mesmo fará cos castrexos do noso NO. Que tódolos motivos da decoración latènica ou castrexa proceden do Exeo (sobre un fondo hallstáttico) está fóra de dúbida. Algo diferente será a súa plasmación, pois entre os galos "...o resultado final será rabiosamente cuvilíneo.." (Hawkes, 1965: 211), mentras que aquí triunfará o clasicismo, a pureza do motivo sobre o seu desenrolo gráfico. Se nun museo xuntaramos tódalas pezas en pedra creto-micénicas, castrexas e laténicas, eu só sería quen de afasta-las últimas, as demais son intercambiables. Do mesmo xeito, calquera dos motivos que collamos na plástica castrexa ten idénticos paralelos na arte romana republicana e imperial en sartegos, vasos, mosaicos, etc. ...

Por último quero apuntar que, para min, a gramática decorativa castrexa só ten valor de ornamento. Se, como se ten defendido, tivera unha significación simbólico-relixiosa, non é doado explicar como despois da gran producción da época Xulio-Claudia, as pezas son crebadas e reaproveitadas como material constructivo nas edificacións feitas na segunda metade do s. I d.C. Por mor da brevidade citemos tan só o seguinte: "Cada símbolo religioso está destinado a convertirse con el curso del tiempo en un motivo predominante o exclusivamente decorativo, no bien posea cierta cualidad artística" (Rielgl, 1980: 35).

"CUADERNOS DE ESTUdIOS GALLEGOS", Tomo XLI, Fascículo 106, Santiago 1993-94. 


\section{PEDRAS FORMOSAS}

Desde que no século pasado se descubriu para a ciencia a "Pedra Formosa" de Briteiros, o número de exemplares foi medrando tanto en pedras soltas como en "fornos" máis ou menos completos: Briteiros (2), Saia, Galegos, Freixo, Sanfins, Sardoura, Armea, Castro das Eiras e moi posiblemente Vermoim, e Grovos, todos eles no Convento Bracarense; Coaña e dous en Pendia en Asturias. Tense incluído con reservas un en Borneiro e en 1987 excavouse outro en Punta dos Prados (Ortigueira). No mapa xeral só aparecen os que teñen pedra decorada.

A estructura deste tipo de construcción, que se repite en tódolos descubertos, organízase axialmente en catro espacios: adro aberto con piscina á que chega unha canle de auga, antecámara e cámara separadas pola "pedra formosa" e forno. A "pedra formosa" pode estar decorada ou non e, caso de estalo, os motivos son diferentes nas distintas pedras e repítense nas decoracións das casas. Coido que este punto ten interés á hora de procurar unha función para estes recintos. Se a primeira das atopadas está toda ela cuberta de motivos variados, outras, como as de Sanfins e Freixo soluciónanse cun sinxelo cordado. Esto faime pensar que toda a gramática decorativa castrexa, como xa dixen antes, era simplemente ornamental e que os fornos, edificios públicos, se decoraban co gusto da época como unha construcción máis ou nin tan siquera se decoraban, o que cecais sexa aínda máis significativo.

Desde que se descubriu a primeira de Briteiros escomenzaron as interpretacións. Para Hübner (1879: 19) sería un monumento funerario, para Sarmento (imaxinábaa deitada) unha ara de sacrificios (Sarmento, 1879b: 16-32). Outras teorías: "accubitum prerromano" adicado ó culto fálico (Cabré, 1922: 74-78), ara de sacrificios sanguinarios ou incruentos (Cardozo, 1929: 99), templo adicado á "Agua" (Azevedo, 1946: 150-164), obradoiros para templa-lo ferro (Monteagudo, 1952: 114), fornos de panificación (Gómez Tabanera, 1980: 98), etc. ...

Conde-Valvís propón unha nova hipótese. Para el serían termas (Conde-Valvís, 1955: 432-446). Esta idea vai ser asumida, despois das súas excavacións en Sanfins, por Almeida (1974: 149-172) e posteriormente por Silva (1986) quen excavará o de Galegos.

Se voltamos á estructura destas construccións vemos que estamos diante da disposición típica das termas romanas: frigidarium, tepidarium e caldarium. Certamente só había auga no primeiro, pero podemos pensar nunha vaporización introducíndoa no caldarium, o que por outra banda 


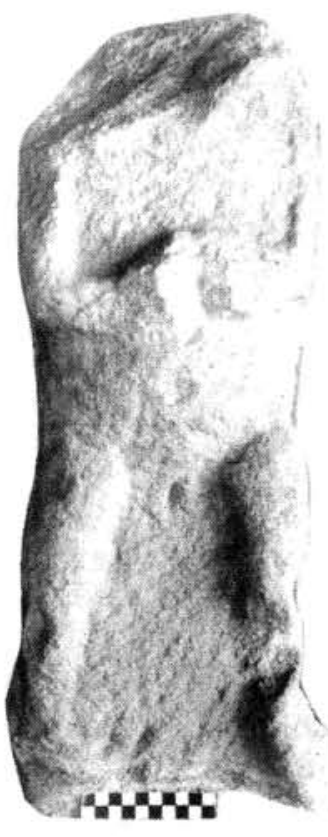

1

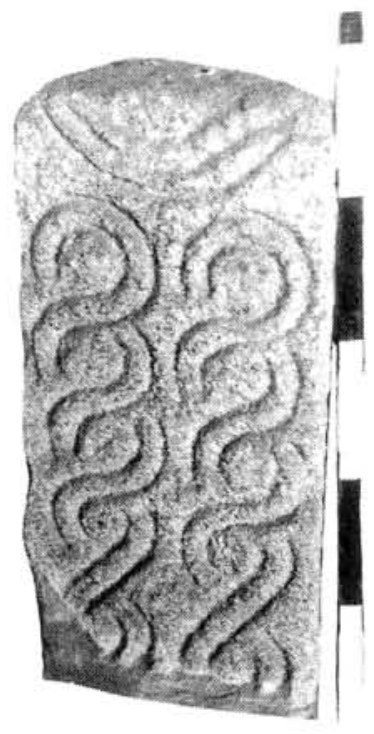

2

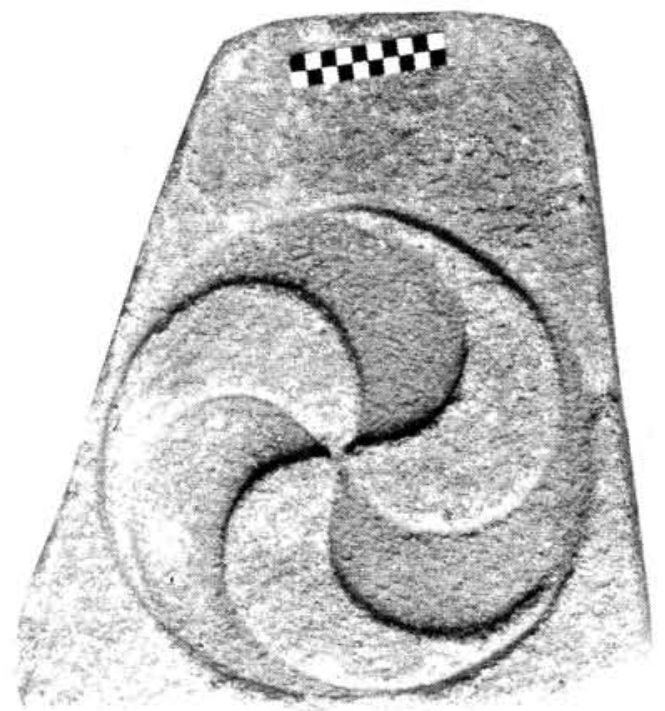

3

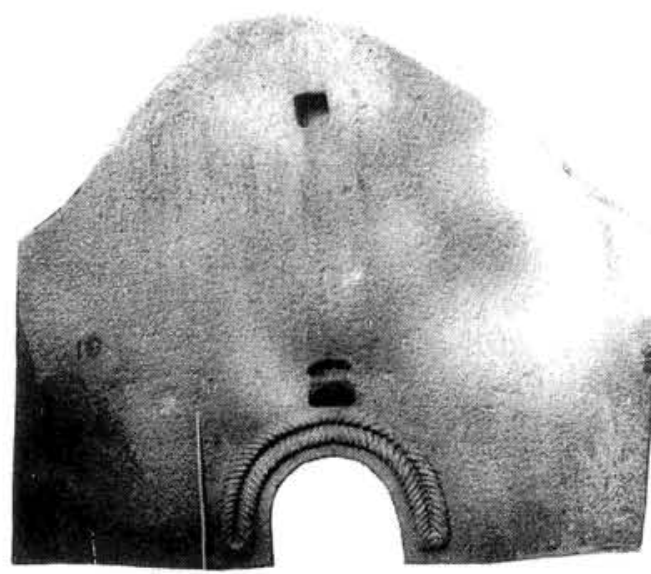

4

Lámina 2

1.- Figura de Sendim -2.- Pedra decorada de Monte Redondo 3.- Trisquel de San Cibrán de Las -4.- Pedra Formosa de Sanfins. 
tampouco sería imprescindible.

A "pedra formosa" non esta'na fachada, senón separando o caldarium do tepidarium, é dicir, no lugar de maior permanencia, o mesmo que sucedía nas termas romanas onde "Los interiores estaban suntuosamente decorados...; el exterior, en cambio, solía carecer completamente de ornamentación" (Blagg, 1985: 69). Este autor engade na mesma páxina que os baños romanos das casas particulares tiñan tamén os tres elementos fundamentais e que "Un rasgo básico de los grandes baños públicos fue su trazado simétrico en torno a un eje que comenzaba en la entrada principal...". Xustamente esto é o que sucede nos castrexos, onde a simetría axial é perfecta.

Por suposto, a cronoloxía dos excavados lévanos ó s. I d.C.

Para rematar este apartado direi que se ten tentado atopar unha explicación simbólica ó feito de que en varios casos algunhas pedras do "forno" teñan un enorme desgaste, vg. no tanque do da Saia, que mesmo afectou ós togados alí esculpidos. Coido que a explicación desto é máis sinxela e prosaica: nun lugar en pleno monte, onde hai auga e pedras fixas labradas e de boa calidade, serían moitas as ferramentas de traballo que, ó longo dos séculos, se terían afiado, sen importar ás xentes "doutra cultura" chegar a destrozar relevos que nada lles dicían.

\section{CONCLUSIÓN}

Cando hai moitos anos encetei o estudio da plástica castrexa, esta considerábase prerromana de orixe céltica. Eu partín cun espíritu cartesiano recollendo todo o material disperso, ubicándoo nos respectivos xacementos e estudiando polo miudo cada un deles (revisións bibliográficas, análises dos materiais, varificacións no terreo, etc.), chegando á conclusión de que tódolos castros con escultura (máis de cen) e que deron materiais datables, ou ben desenrolaron toda a súa actividade no cambio de Era e s. I d.C., ou ben foi ese o período álxido de ocupación. Un bo exemplo do primeiro sería Monte Mozinho, con dous niveis: Augusto-Flavios. Exemplo do segundo sería, entre outros, S. Julião, xa cunha importante ocupación no Bronce Final e no que se fixo unha gran remodelación mesmo con áreas empedradas en época de Augusto, xusto onde apareceu o guerreiro galaico...

Así cheguei á conclusión de que esta plástica non é anterior a Augusto e, tendo en conta que cando aparece en niveis Flavios está reaproveitada, deixa de se facer no derradeiro tercio do s. I d.C.

"CUADERNOS DE ESTUdios GALLEGOS", Tomo XLI, Fascículo 106, Santiago 1993-94. 
Farase baixo Roma e pola súa influencia. O guerreiro castrexo será a adaptación das estatuas públicas romanas que se están a erguer na capital do "núcleo" de Braga; as cabezas humanas, non "têtes coupées", son idénticas a tantas aparecidas na propia Italia e en todo o Imperio no s. I; os "fornos" derivan das termas; as decoracións son mediterráneas e empregadas na propia Roma, etc., etc. O celtismo está aquí fóra de lugar, o mesmo que as revisións dos últimos anos están a constatar para pezas indiscutiblemente célticas que van desde as cabezas das fontes do Sena ó Jano de Holzgerlingen (Cfr. Deyts, 1966: 200-202, que o traslada do s. VI a.C. ó s. I d.C.) ata ó caldeiro de Gundestrup que de momento tamén "camiñou" ata a época de Augusto...

É posible que moitas cuestións non quedaran suficientemente claras, pero unha conferencia non da para máis e as argumentacións, exemplos, paralelos e teorías que xuntei nun milleiro de páxinas dificilmente se poden condensar neste pequeno artigo.

\section{BIBLIOGRAFÍA}

ACUÑA CASTROVIEJO, Fernando (1980): "A Prehistoria e a Edade Antiga" In Historia de Galicia, I. Cupsa Editorial-Editorial Planeta, Barcelona, 31-106

ALARCÃO, Jorge (1986): "Arte do Bronze Final e da Idade do Ferro". In Historia da Arte em Portugal, 1 do Paleolítico à arte visigótica. Alfa, S.A. Lisboa, 57-65.

(1988): "O dominio romano em Portugal". F.H. Publicações EuropaAmérica. Mira-Sintra.

ALMEIDA, Carlos Alberto Brochado de (1983): "A cabeça de guerreiro galaico da citânia de Roriz-Oliveira (Barcelos)". Barcellos-Revista I, $\mathrm{n}^{\circ} 2$, Barcelos, 81-90.

ALMEIDA, Carlos Alberto Ferreira de (1974): "O monumento con forno de Sanfins e as escavações de 1973". Actas do III Congreso Nacional de Arqueología, vol. I, Porto, 149-172.

(1975): "Influencias meridionais na cultura castreja". XIII Congreso Arqueológico Nacional. Huelva (1973), Zaragoza, 491-498.

(1981): "Nova estátua de guerreiro galaico-minhoto (Refojos de Bas-

"CUADERNOS DE ESTUDIOS GALLEGOS", Tomo XLI, Fascículo 106, Santiago 1993-94. 
to)". Arqueología, no 3. G.E.A.P., Porto, 111-116.

(1982): "Resposta (a Uma carta... de SILVA) (1982)". Arqueología, n ${ }^{\circ}$ 5. G.E.A.P., Porto, 82-84.

(1983): "O Castrejo sob o dominio romano: a sua transformação". In PEREIRA MENAUT (ed.): Estudos de Cultura Castrexa e Historia Antiga de Galicia. Universidade de Santiago-Instituto de Estudios Gallegos Padre Sarmiento, Santiago 187-198.

AZEVEDO, António de (1946): "O Monumento Funerario de Citânia (nova interpretação)". Revista de Guimarães, LVI (1-2), Guimarães, 150-164.

BALIL ILLANA, Alberto (1974): "Sobre la escultura y las artes de la Península Ibérica en época romana". Revista de Guimarães, LXXXIV (1-4), Guimarães, 95-124.

(1978): "Esculturas de época romana en Galicia (Aspectos y Problemas"). Revista de Guimarães, LXXXVIII, Guimarães, 147-157.

BENOIT, Fernand (1949): "L'aire méditerranéenne de la "tête coupée". Rivista di Studi Liguri, Anno XV, núms. 3-4, Bordighera, 243-255.

(1959): Mars et Mercure. Nouvelles recherches sur l'interpretation gauloise des divinités romaines. Publications des Annales de la Faculté des Lettres. Aix-en-Provence, Nouvelle Série, nº 25. Ed. Ophrys.

BLAGG, Thomas (1985): "La arquitectura" in HENIG, M.: El arte romano. Ediciones Destino, Barcelona, 29-75.

BLANCO FREIJEIRO, Antonio (1956): "Cabeza de un castro de Narla. Notas sobre el tema de la cabeza humana en el arte céltico". Cuadernos de Estudios Gallegos, T. XI, fasc. XXXIV, Santiago, 159-180. (1971): "Monumentos romanos de la conquista de Galicia" Habis, Universidad de Sevilla, 2. Sevilla, 223-232.

BLÁZQUEZ MARTÍNEZ, José Ma . (1960). "Cabezas célticas inéditas del castro de Yecla, Salamanca". VII Congreso Nacional de Arqueología, Barcelona 1960. Zaragoza, 217-226.

BOSCH GIMPERA, Pedro (1921): "Los celtas y la civilización céltica en la Península Ibérica". Boletín de la Sociedad Española de Excursiones, año 29. Madrid, 248-300.

"CUADERNOS DE ESTUdiOS GALLEGOS", Tomo XLI, Fascículo 106, Santiago 1993-94. 
(1945): La formación de los pueblos de España. México.

BOUZA BREY, Fermín (1951): "La cabeza céltica de Ocastro (Silleda)". Cuadernos de Estudios Gallegos, T. VI, fasc. XVIII Santiago, 33-42.

CABRÉ Y AGUILÓ, Juan (1922): "Una nueva hipótesis acerca de 'Pedra Formosa' de la Citania de Sabroso" (sic). Sociedad Española de Antropología Etnografia y Prehistoria, T. I, Año I, Madrid, 74-78.

CABRÉ DE MORÁN, E. e MORÁN CABRÉ, J.A. (1979): "Aportación al estudio tipológico de las espadas 'Alcácer do Sal'. Una nueva serie descubierta en la necrópolis de la Orera (Chamartín de la Sierra, Ávila)". XV Congreso Nacional de Arqueología (Lugo, 1977), Zaragoza, 763774.

CALO LOURIDO, Francisco (1976): "Revisión metodológica sobre un supuesto ídolo fálico". Boletín Auriense, T. VI, Ourense, 87-96.

(1983): "Arte, decoración, simbolismo e outros elementos da cultura material castrexa - Ensaio de síntese". In Pereira Menaut (ed.): Estudos de Cultura Castrexa e Historia Antiga de Galicia. Universidade de Santiago e Instituto de Estudos Galegos Padre Sarmiento, Santiago, 159-185.

(1993): A Cultura Castrexa. Historia de Galicia, 3. Edicións A Nosa Terra. Porto.

(1994): A Plástica da Cultura Castrexa Galego-Portuguesa. Fundación "Pedro Barrié de la Maza, Conde de Fenosa". Catalogación Arqueológica y Artística del Museo de Pontevedra. Pontevedra.

CARDOZO, Mário (1929): "A pedra formosa". Revista de Guimarães, XXXIX, Guimarães, 87-102.

(1973a): "Breves considerações sobre a escultura primitiva de Lusitania pré-e protohistórica". Cuadernos de Estudios Gallegos, T. XXVIII, fasc. 85, Santiago, 153-160.

(1973b): "La culture des castros du Nord du Portugal". Trabalhos de Antropologia e Etnologia, vol. XXII, fasc. 3, Porto, 261-290.

CONDE-VALVÍS FERNÁNDEZ, Francisco (1950-51): "La 'cibdá' de Armea en Santa Marina de Aguas Santas". Boletín del Museo Arqueológico Provincial de Orense. T. VI, Ourense, 25-89.

"CUADERNOS DE ESTUdios GAlLEGOS", Tomo XLI, Fascículo 106, Santiago 1993-94. 
(1955): "Las termas romanas de la 'cibdá' de Armea en Santa María (sic) de Aguas Santas". III Congreso Nacional de Arqueología (Galicia, 1953), Zaragoza, 432-446.

DÉCHELETTE, Joseph (19ْ09): "Essai sur la cronologie de la Péninsule Ibérique". Révue Archéologique, T. XIII, París, 25-36.

DEONNA, W. (1929): "La vie millénaire de quelques motifs decoratifs". Genava, VII. Genebre, 172 e ss.

DEYTS, Simone (1966): "Les différents 'styles' de sculptures en bois des sources de La Seine". Révue Archéologique de l'Est et du Centre Est, pp. 198-211.

DUVAL, Paul-Marie (1957): Les dieux de La Gaule. Presses Universitaires de France, 108. París.

FARIÑA BUSTO, F., ARIAS VILAS, F. e ROMERO MASIÁ, A. (1983): "Panorámica general sobre la cultura castrexa". In PEREIRA MENAUT (ed.): Estudos de Cultura Castrexa e Historia Antiga de Galicia. Universidade de Santiago e Instituto de Estudos Galegos Padre Sarmiento, Santiago, 87-127.

FARIÑA BUSTO, F., CALO LOURIDO, F. e ACUÑA FERNÁNDEZ, P. (s/d): "Escultura castrexa" in Gran Enciclopedia Galega, T. X. Vitoria, 116-125.

FERRO COUSELO, Xesús (1972): "Estatuas sedentes y una columna miliaria de Xinzo de Limia". Boletín Auriense, Ano II, T. II, Ourense, 329-335.

FERRO COUSELO, X. e LORENZO FERNÁNDEZ, X. (1976): "Excavaciones en el Castromao. Celanova, Orense". Noticiario Arqueológico Hispano, Prehistoria, 5. Madrid, 349-354.

GÓMEZ TABANERA, J.M. (1980): "Aspectos de la cultura castreña en sus manifestaciones en Asturias y de los modos de producción en las sociedades protohistóricas del NW de la Península Ibérica". Seminário de Arqueologia do Noroeste Peninsular. vol. II. Guimarães, 87-110. 
GUERRA, Luis Figueiredo da (1899-1990): "Vestigios romanos no concelho de Viana do Castelo" O Arqueólogo Portugués, vol. V, Lisboa, 175-177.

HAWKES, Christopher (1965): "El arranque de Europa" in HUIGHE: El arte y el hombre, I. Ed. Planeta S.A., Barcelona, 203-216.

HÖCK, Martin (1984): "Acerca dos elementos arquitectónicos decorados de castros do noroeste peninsular". Revista de Guimarães, XCIV, Guimarães, 389-405.

HÜBNER, Emilio (1861): "Statuen galläkischer Krieger in Portugal und Galicien". Denkmaller und Forschungen. Archäelogische Zeitung, $\mathrm{n}^{\circ}$ 154,186 e ss.

(1879): "Citânia". Archeologia Artistica, T. I, fasc. V. Porto.

JUNIOR, J.R. dos Santos (1975): "A cultura dos berrões no Nordeste de Portugal". Trabalhos de Antropologia e Etnologia, XXII, fasc. IV. Porto, 353-516.

(1985): "A cultura dos berrões proto-históricos fundamente radicada en Tras-os-Montes". Trabalhos de Antropologia e Etnologia, XXV, fasc. 1, Porto, 31-40.

LÓPEZ CUEVILLAS, Florentino (1933): "A área xeográfica da cultura norte dos castros". In Homenagem a Martins Sarmento, Guimarães, 99-107.

(1951): "Esculturas zoomorfas y antropomorfas de la Cultura de los Castros". Cuadernos de Estudios Gallegos, VI, fasc. XIX, Santiago, 177-203.

(1953): La civilización céltica en Galicia. Porto y Cia. Santiago.

(1958): "Lápidas romanas de la provincia de Orense". Cuadernos de Estudios Gallegos, XIII, fasc. XLI, Santiago, 343-358.

LÓPEZ MONTEAGUDO, Guadalupe (1989): Esculturas zoomorfas celtas de la Península Ibérica. Anejos de Archivo Español de Arqueología, X. C.S.I.C., Madrid.

MALUQUER DE MOTES, Juan (1963): "Pueblos celtas" in MENÉNDEZ PIDAL: Historia de España, T. I, Espasa-Calpe, S.A., Madrid.

"CUADERNOS DE ESTUDIOS GALLEGOS", Tomo XLI, Fascículo 106, Santiago 1993-94. 
(1975): "Formación y desarrollo de la cultura castreña". Actas de las I Jornadas de Metodología Aplicada de las Ciencias Históricas. I. Prehistoria e Historia Antigua (1973). Universidad de Santiago, Vigo, 269284.

MARTIN, Henri (1881): "La citania de Briteiros". Révue Archéologique, $n^{\circ}$ 42, París, 160-164.

MONTEAGUDO GARCÍA, Luis (1952): "Monumentos propiedad de la Sociedad Martins Sarmento". Archivo Español de Arqueología, XXV, Madrid, 112-116.

MURGUÍA, Manuel (1901): Historia de Galicia. T. I, $2^{\mathrm{a}}$ ed., Coruña. (1906): Historia de Galicia, T. II, $2^{\mathrm{a}}$ ed., Coruña.

OLIVEIRA, Ernesto V. de, GALHANO, F. e PEREIRA, B. (1988): Construções primitivas em Portugal. Publicacões Don Quixote, Lisboa $\left(1^{\text {a }}\right.$ ed. 1969).

PARIS, Pièrre (1903a): Essai sur l'art et l'industrie de l'Espagne primitive. T. I, Paris.

(1903b): "Statues lusitaniennes de style primitive". O Arqueólogo Portugués, VIII, nº 1. Lisboa, 1-8.

PEIXOTO, Rocha (1903): "Um guerreiro lusitano". In O Primeiro de Janeiro, 14-maio. Porto, 2.

(1905-08): "Prisões' de gado". Portugalia, II. Porto, 78-79.

PEREIRA, Félix Alves (1908): "Novo material para o estudo da estatuária e architectura dos castros do Alto Minho". O Arqueólogo Portugués, XIII, núms. 7-12, Lisboa, 202-244.

PEREIRA MENAUT, Gerardo (1980): "Historical landscape and structures. A reflection on the case of Roman Galicia". Boletin Auriense, $\mathrm{X}$, Ourense, 25-32.

PLÁCIDO SUÁREZ, Domingo (1989): "El Alto Imperio" in DOMÍNGUEZ ORTIZ, Antonio: Historia de España, T. II. Planeta, Barcelona, 163-314.

"CUADERNOS DE ESTUdiOS GALLEGOS", Tomo XLI, Fascículo 106, Santiago 1993-94. 
RIEGL, Alois (1980): Problemas de estilo. Fundamentos para una historia de la ornamentación. G.G. Arte. Ed. Gustavo Gili, S.A., Barcelona ( $1^{\text {a }}$ ed. Berlim, 1893).

RIVAS QUINTAS, Eligio (1985): A Limia... Diputación Provincial de Ourense. Servicio de Publicaciones. Ourense.

RODRÍGUEZ COLMENERO, Antonio (1977): Galicia Meridional Romana. Universidad de Deusto, Valencia.

SARMENTO, Francisco Martins (1879a): "Arte pre-romana". O Occidente, II, $\mathrm{n}^{\circ}$ 44, Lisboa, 15-X-1879, 157-158.

(1879b): Observacões à Citânia do Sr. Doutor E. Hûbner. Porto. (46 pp.).

(1881): "A estátua do Patio da Morte". O Pantheón, ano I, Porto, 382. (1882): "Se antes da invação dos romanos havia uma arte entre nós". $A$ Arte Portuguesa. T. I (4), Porto, 1-3, 19-21 e 26-27.

(1886): "Estátuas militares no Jardim Botánico da Ajuda". O Occidente, vol. IX, $\mathrm{n}^{\circ} 283$, Lisboa, 246 e 248.

(1896): "A propòsito das estátuas Galaicas". Revista de Sciencias Naturaes e Sociaes, IV, Porto, 181-188.

(1899): "A Arte Micénica do Noroeste de España". Portugalia, I, Porto, 1 e ss.

SILVA, Armando Coelho Ferreira da (1981/82): "Novos dados sobre a organização social castreja". Portugalia, Nova Série, vol. II-III, Porto, 83-94.

(1986): A Cultura Castreja no Noroeste de Portugal. Museu Arqueológico da Citânia de Sanfins. Paços de Ferreira.

SILVA, Ma de Fátima Matos da (1986): "Subsídios para o estudo da Arte Castreja. Arte Decorativa Arquitectónica". Revista de Ciências Históricas. Universidade Portucalense, I, Porto, 31-68.

TABOADA CHIVITE, Jesús (1946): "El castro de Florderrey Vello (Villardevós) y sus interesantes hallazgos". Boletín del Museo Arqueológico Provincial de Orense, II. Ourense, 37-43.

(1948): "Esculturas de verracos en Galicia". Archivo Español de Arqueología, LXXII, Madrid, 291-294.

"CUADERNOS DE ESTUdios GALLEGOS", Tomo XLI, Fascículo 106, Santiago 1993-94. 
(1949): "La cultura de los verracos en el noroeste hispánico". Cuadernos de Estudios Gallegos, IV, fasc. XII, Santiago, 5-26.

(1965): Escultura celto-romana. Cuadernos de Arte Gallego, $n^{\circ} 3$. Ed. Castrelos, Vigo.

TARACENA, Blas (1943): "Cabezas-trofeo en la España céltica". Archivo Español de Arqueología, XVI, nº 51, Madrid, 157-171.

TEIXEIRA, Carlos (1940): "O castro de Lanhoso e o seu espolio". Congresso do Mundo Português, vol. I. Lisboa, 517-529.

THÉVENOT, Emile (1972): Les Gallo-Romaines. Que sais-je?, no 314. Presses Universitaires de France. Paris.

TRANOY, Alain (1981): La Galice romaine. Recherches sur le Nord-Ouest de la Péninsule Ibérique sous l'Antiquité. Publications du Centre Pierre Paris, 7. París.

(1988): "Du heros au chef. L'image du guerrier dans les sociétés indigènes du Nord-Ouest de la Péninsule Ibérique (IIe. siècle avant J. C -Ier. siècle après J.-C.)". Caesarodunum. Tome XXIII. Ed. Corance, 219-227.

VASCONCELOS, José Leite de (1896): "Estátuas de guerreiros lusitanos". O Arqueólogo Portugués, II, fasc. 1. Lisboa, 29-32.

(1901): "Extractos da correspondencia de F. Martins Sarmento (18811883)". O Arqueólogo Portugués, VI, fasc. 1-2. Lisboa, 30-48.

VÁZQUEZ SEIJAS, Manuel (1933): "El castro de Barán". Boletín de la Real Academia Gallega, XXI, n² 246. A Coruña, 125-130.

VÁZQUEZ VARELA, José Manuel (1982): "Arte prehistórico" in VV.AA.: Historia del Arte Gallego. Ed. Alhambra, Madrid, 1-52.

WOLF, Eric R. (1982): Los campesinos. Editorial Labor, S.A. 